\section{Deltavir cohort} HDV in France

$$
n=1112
$$

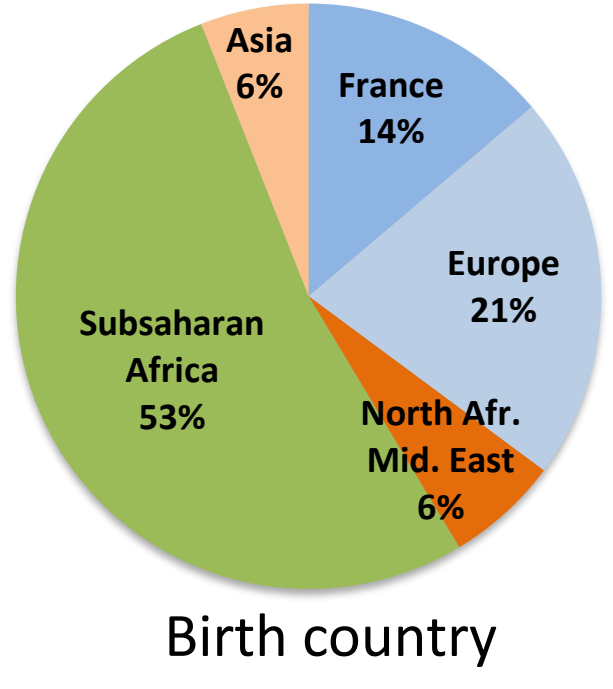

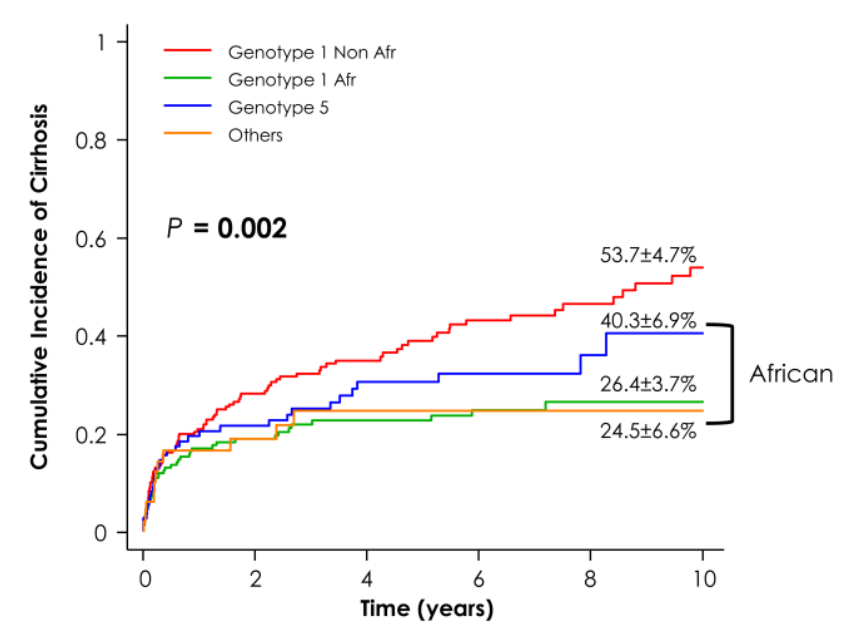

Treatment response

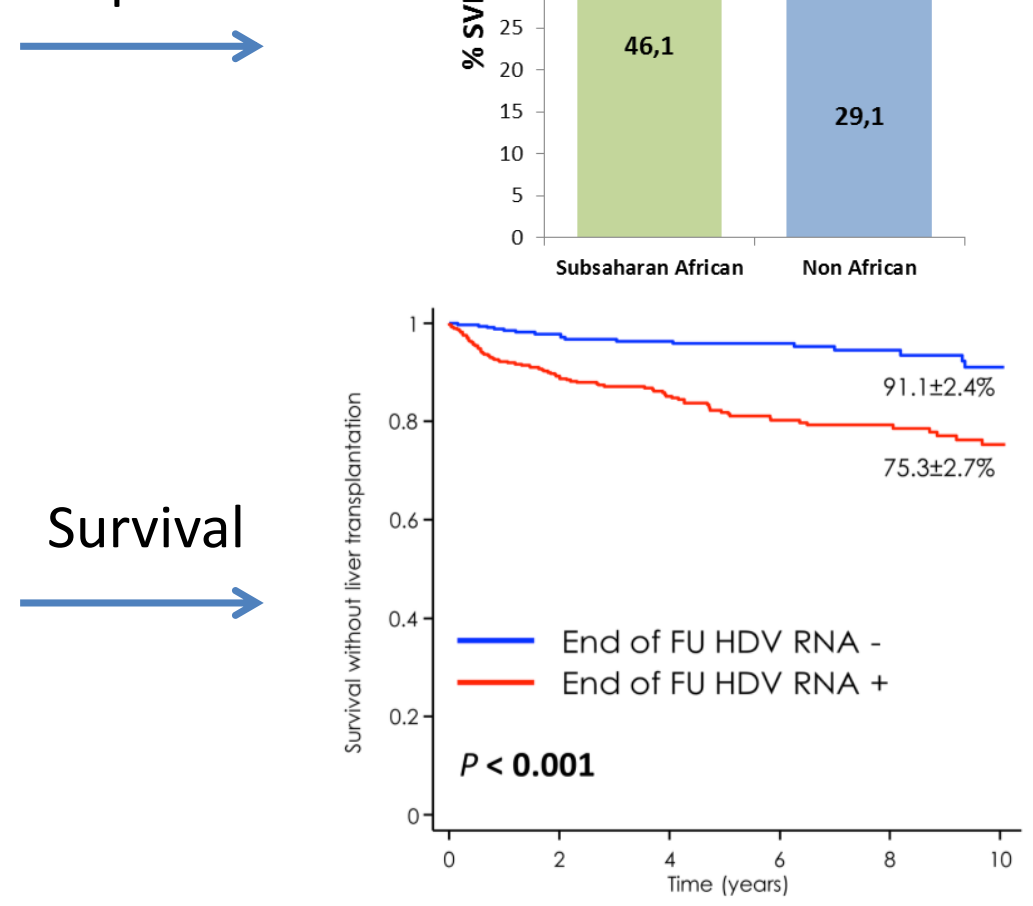




\section{Origin, HDV genotype and persistent viremia determine outcome and treatment response in patients with chronic hepatitis Delta}

Dominique Roulot* ${ }^{1}$, Ségolène Brichler* ${ }^{2}$, Richard Layese ${ }^{3}$, Zahia BenAbdesselam ${ }^{4}$, Fabien Zoulim $^{5}$, Vincent Thibault ${ }^{6}$, Caroline Scholtes ${ }^{7}$, Bruno Roche ${ }^{8}$, Corinne Castelnau ${ }^{9}$, Thierry Poynard ${ }^{10}$, Olivier Chazouillères ${ }^{11}$, Nathalie Ganne ${ }^{12}$, Hélène Fontaine ${ }^{13}$, Jerome Gournay ${ }^{14}$, Dominique Guyader ${ }^{15}$, Frédéric le Gal ${ }^{2}$, Pierre Nahon ${ }^{12}$, Françoise Roudot-Thoraval** ${ }^{3,16}$, Emmanuel Gordien**2 ${ }^{2}$ and the Deltavir study group $* * *$.

* equally contributing first authors

**equally contributing last authors

${ }^{1}$ AP-HP, Hôpital Avicenne, Unité d'hépatologie, Université Paris 13, Bobigny ; Inserm U955, équipe 18, Université Paris-Est, Créteil

${ }^{2}$ AP-HP, Hôpital Avicenne, Laboratoire de microbiologie Clinique, Université Paris 13, Centre national de référence des hépatites B, C et Delta, Bobigny, Inserm U955, équipe 18, Université Paris-Est, Créteil

${ }^{3}$ AP-HP, Hôpital Henri-Mondor, Unité de Recherche Clinique, Université Paris-Est, DHU ATVB, IMRB- EA 7376 CEpiA (Clinical Epidemiology and Ageing Unit), Créteil

${ }^{4}$ AP-HP, Hôpital Avicenne, Unité d'hépatologie et Centre de Recherche Clinique, Bobigny

${ }^{5}$ Hospices civils de Lyon, Hôpital Croix Rousse, Service d'hépatologie ; Inserm U1052 ; Université de Lyon

${ }^{6}$ CHU de Rennes, Inserm, EHESP, Irset-UMR S1085, Rennes

${ }^{7}$ Hospices civils de Lyon, Hôpital Croix Rousse, Département de virologie, Université de Lyon

${ }^{8}$ AP-HP, Hopital Paul Brousse, Service d'hépatologie, Villejuif 


\section{Journal Pre-proof}

${ }^{9}$ AP-HP, Hopital Beaujon, Service d'hépatologie, Clichy

${ }^{10}$ AP-HP, Groupe hospitalier Pitié-Salpêtriere, Service d'hépatologie, Sorbonne Université, Paris

${ }^{11}$ AP-HP, Hopital Saint-Antoine, Service d'hépatologie et Centre de Recherche, Inserm, Sorbonne Université, Paris.

${ }^{12}$ AP-HP, Hôpital Jean-Verdier, Service d'hépatologie, Bondy, Université Paris 13, Bobigny; Inserm U1162, Université Paris 5, Paris

${ }^{13}$ AP-HP, Hôpital Cochin, Service d'hépatologie, Paris

${ }^{14}$ CHU de Nantes, Hopital Hôtel Dieu, Département d'hépatogastroentérologie, Nantes

${ }^{15}$ CHUde Rennes, Service d'hépatologie, Rennes

${ }^{16}$ AP-HP, Hôpital Henri-Mondor, Service d'hépatologie, Créteil

Deltavir study group***:

Jean-Didier Grangé (AP-HP, Hôpital Tenon, Service d’hépatologie, Paris) ;

Roland Landman(AP-HP, Hôpital Bichat, Service de maladies infectieuse et tropicales, Paris) ; Christophe Hezode (AP-HP, Hôpital Henri-Mondor, Service d'hépatologie, Créteil) ;

Ghassan Riachi (Hôpital Charles-Nicolle, Service d'Hépatologie, Rouen;

Caroline Lascoux-Combe(AP-HP, Hôpital Bichat, Service de maladies infectieuse et tropicales, Paris); Véronique Loustaud-Ratti (CHU de Limoges, Département d'hépato-gastroentérologie, Limoges; Isabelle Rosa (CHIC, Département d’hépato-gastroentérologie, Créteil;

Philippe Mathurin (Hôpital Claude Huriez, Service d'hépatologie, Lille) ; Eric Nguyen-Khac (Hôpital Amiens Nord, Service d'Hépatologie, Amiens); Xavier Causse (CHR d'Orléans, Département d'hépato-gastroentérologie et oncologie, Orléans); Sylvie Naveau(AP-HP, Hôpital Antoine Béclère, Service d'hépato-gastroentérologie, Clamart); François Habersetzer (IHU de Strasbourg, Unité d'hépatologie, Strasbourg); Sophie Metivier (CHU Purpan, 
Département d'hépato-gastroentérologie, Toulouse); Hélène Labadie (Hopital Delafontaine, Service d'hépato-gastroentérologie, Saint Denis); Pierre Sellier (AP-HP, Hôpital Lariboisière, Service de médecine interne, Paris); Julie Bottero (AP-HP, Hôpital Saint Antoine, Service de maladies infectieuse et tropicales, Paris); Victor de Ledinghen (CHU de Bordeaux, hôpital Haut-Lévêque, Service d'hépato-gastroentérologie,Pessac); Laurent Alric (CHU Purpan, Service de médecine Interne-Pôle Digestif UMR 152, Toulouse) ; Paul Calès (CHU d'Angers, Service d'Hépatologie, Angers); Cecile Goujard (AP-HP, Hôpital Kremlin-Bicêtre, Service de médecine interne, le Kremlin-Bicêtre); Jean-François Cadranel ( Centre hospitalier Laennec, Service d'hépato-gastroentérologie et nutrition, Creil); Dominique Salmon (AP-HP, Hôpital Cochin, Service de maladies infectieuse, Paris); Sophie Hillaire (Hôpital Foch, Service de médecine interne, Suresnes).

\section{Corresponding author:}

Dominique Roulot, MD, PhD

Unité d'Hépatologie, Hôpital Avicenne, 125 route de Stalingrad 93009 Bobigny

Tel 331489554 30; Fax 33148955450

dominique.roulot@aphp.fr

Grant support: ANRS (France REcherche Nord \& sud Sida-HIV Hépatites-FRENSH).

Abbreviations: Hepatitis Delta Virus (HDV), Hepatitis B virus (HBV), French National Reference Centre (FNRC), hepatic decompensation (HD), hepatocellular carcinoma (HCC), liver transplantation (LT), MRI (magnetic resonance imagery), computerized tomography-scan (CT-scan), Human Immunodeficiency Virus (HIV), hepatitis C virus (HCV), Alanine aminotransferase (ALT), Aspartate aminotransferase (AST), gamma glutamyl transferase (GGT), alpha-feto protein (AFP), Body Mass Index (BMI), Standard Deviation (SD), Interquartile Range (IQR), Hazard Ratio (HR), Confidence Interval (CI), International Units 
(IU), European Association for the Study of the Liver (EASL), Polymerase Chain Reaction (PCR), Open Reading Frame (ORF), Intravenous Drug User (IVDU).

\section{Disclosures:}

Dr. Nahon received honoraria from Astra-Zeneca, Abbvie, Bayer, Bristol-Myers Squibb, Gilead and Ipsen. He consults for Abbvie and Bristol-Myers Squibb.

Dr Roudot-Thoraval received honoraria from Gilead and AbbVie.

Dr Roulot received honoraria from Gilead.

Author contributions: Drs. Roulot, Brichler, Roudot-Thoraval had full access to all data in the study and take responsibility for data integrity and the accuracy of data analysis.

Study concept and design: Roulot, Brichler, Roudot-Thoraval.

Acquisition of data: BenAbdesselam, Roulot, Brichler, Gordien, Zoulim, Thibault, Scholtes,

Roche, Castelnau, Poynard, Chazouillères, Ganne, Fontaine, Gournay, Guyader, Le Gal, Layese and the Deltavir Study collaborators.

Analysis and interpretation of data: Roulot, Brichler, Layese, Roudot-Thoraval.

Drafting of the manuscript: Roulot, Brichler, Roudot-Thoraval.

Critical revision of the manuscript for important intellectual content: Roulot, Brichler, Gordien, Nahon, Layese, Roudot-Thoraval.

Statistical analysis: Layese, Roudot-Thoraval

Obtained funding: Roulot

Administrative, technical and material support: BenAbdesselam, Roulot, Brichler, Layese, Roudot-Thoraval, Gordien.

Study supervision: Roulot, Brichler.

Word count: 6590

Short title: Factors affecting outcome of chronic hepatitis delta

Items: Figures: 2, Tables: 6 
ABSTRACT (word count: 275)

Background/Aims: Hepatitis delta virus (HDV) infection causes severe chronic liver disease in Hepatitis B virus (HBV) infected individuals. Factors associated with poor prognosis are largely unknown.

Methods: The French National Reference Centre for HDV performed a nationwide retrospective study on $1112 \mathrm{HDV}$-infected patients, collecting epidemiological, clinical, virological and histological data from the initial referral to the last recorded follow-up.

Results: $68.6 \%$ of patients were male with a median age of 36.5 [29.9-43.2] years. Most patients with known birth place were immigrants from sub-Saharan Africa (52.5\%), southern and eastern Europe (21.3\%), northern Africa and the Middle East (6.2\%), Asia (5.9\%) and South America (0.3\%). Only 150 patients (13.8\%) were french native. HDV load was positive in 659 of 748 tested patients $(88.1 \%)$. HDV-1 was predominant $(75.9 \%)$ followed by subSaharan genotypes: HDV-5 (17.6\%), HDV-7 (2.9\%), HDV-6 (1.8\%) and HDV-8 (1.6\%). At referral, 312 patients $(28.2 \%)$ had cirrhosis, half having experienced at least one episode of hepatic decompensation (HD). Cirrhosis was significantly less frequent in African than in European patients regardless HDVgenotype. At the end of follow-up (median 3.0 [0.8-7.2]), $48.8 \%$ of the patients had developed cirrhosis, $24.2 \%$ had one or more episodes of HD and 9.2\% had hepatocellular carcinoma (HCC). European HDV-1 and African HDV-5 patients were more at risk of developing cirrhosis. Persistent replicative HDV infection was associated with decompensation, HCC occurrence and death. African patients displayed better response to interferon therapy than non-African patients $(46.4 \%$ vs $29.1 \%, \mathrm{p}<0.001)$. HDV viral load at baseline was significantly lower in responders than in non-responders.

Conclusion: Place of birth, HDV genotype and persistent viremia constitute the main determinants of liver involvement and response to treatment in chronic HDV-infected patients. 


\section{Lay summary:}

Chronic liver infection by hepatitis delta virus (HDV) emerges as the most severe form of viral chronic hepatitis. Despite the fact that at least 15-20 million people are chronically infected by HDV worldwide, factors determining the severity of liver involvement are largely unknown. By investigating a large cohort of $1112 \mathrm{HDV}$-infected patients followed in France but coming from differents areas of the world we were able to determine that HDV genotype, the place of birth (reflecting both viral and host-related factors) and persistent viremia constitute the main determinants of liver involvement and response to treatment

Keywords (4-5): HDV genotype, HDV persistent viremia, African origin, liver outcome, Deltavir study. 


\section{Introduction}

Hepatitis delta virus (HDV) is a human RNA virus that requires hepatitis B virus (HBV) envelope for assembly and propagation. HDV chronic infection is less frequent than HBV monoinfection, with 15-20 million infected individuals worldwide, compared to 248 million HBV-infected persons ${ }^{1}$, figures which may be underestimated 2-3 times according to a recent meta-analysis ${ }^{2}$. Nevertheless, HDV-HBV infection causes more severe chronic liver disease than HBV infection alone, because of accelerated progression to fibrosis ${ }^{3,4}$, increased risk of cirrhosis decompensation ${ }^{5-7}$ and hepatocellular carcinoma (HCC) ${ }^{8,9}$. Moreover, the current recommended treatment, based on interferon-alpha therapy, has limited effect with less than one-third of the patients becoming long-term responders ${ }^{10}$. Factors associated with worse prognosis and poor response to treatment remain largely unknown.

The outcome of viral infections is shaped by a complex interplay of host genetic factors, viral genotype and adaptive mutations, with potential contribution of environmental factors. For example, the most severe forms of chronic hepatitis delta are observed in very young inhabitants of the Amazonian area, all infected by the HDV-3 genotype. This particular genotype might be responsible for the observed high severity, although specific genetic and/or environmental factors might also contribute to faster disease progression ${ }^{11}$.

Although a comprehensive investigation of the clinical significance of HDV genotypes has not been performed in large cohorts so far, studies on small groups of patients reported that the HDV genotypes might affect the severity of HDV-HBV infection ${ }^{12,13}$. Eight distinct HDV genotypes (HDV-1 to -8) have been identified ${ }^{14,15}$, some genotypes also displaying two to four sub-genotypes ${ }^{16}$. HDV-1, the most prevalent genotype worldwide, comprises four subgenotypes. The ubiquitous HDV-1d sub-genotype is frequent in Europe and Asia, whereas HDV-1a and-1b, were only identified in sub-Saharan Africa. Genotypes 2 and 4 are found in eastern Asia, whereas genotype 3 is restricted to the Amazon region. Genotypes 5 to 8, which 
are exclusively present in Africa, were subsequently characterized by the French National Reference Centre (FNRC) ${ }^{14}$ : HDV-5 is predominant in West Africa, whereas HDV-6, -7 and 8 were isolated in patients from central Africa ${ }^{16}$.

A french study on 2152 clinical strains over a period of 13 years showed that, in addition to the predominant HDV-1 genotype, other genotypes were also represented in the country, likely due to the presence of immigrants originating from all principal geographical areas of the world, mostly from sub-Saharan Africa ${ }^{16}$. The diversity of the HDV-infected population and HDV genotypes in the French cohort provided a unique opportunity to evaluate the role of viral and host factors on the severity of liver involvement and on response to treatment.

In this multicentric study, we characterized epidemiological, clinical, biological, and virological parameters of HDV infection in a large multi-ethnic cohort and identified factors associated with liver complications. 


\section{Patients and Methods}

\section{Patients}

The ethics committee "Comité de Protection des Personnes, Aulnay-sous-Bois, France" approved the Deltavir study protocol. All patients gave written informed consent to participate in the study.

HDV-infected patients were identified from the FNRC database for Hepatitis B, C and delta. The FNRC objective was the prospective collection (starting in 2000) and the genetic characterization of HDV strains isolated from all new patients in France, based on positive total anti-HDV antibodies. In March 2013, 4815 patients had been identified. Deltavir inclusion criteria were: 1) age over 18 years at initial referral; 2) positive HDV serology (total anti-HDV $\mathrm{Ab})$; 3) available medical file with initial clinical and biological evaluations allowing subsequent follow-up; 4) at least one follow-up visit. Exclusion criteria were: 1) positive HDV serology with no file records available; 2) no follow-up visit available. Data collection was carried out for one year. Patient files originated from 34 French centres, distributed all over the territory, specialized in the management of liver or infectious diseases.

\section{Methods}

A dedicated electronic case report form (e-CRF) was created for the study, data being collected retrospectively from medical files. Patient medical files were accessed by clinical research associates who were specifically trained for this study. Data from initial referral (corresponding to the date of initial HDV infection diagnosis) to the last recorded follow-up were recorded anonymously in a computerized database. Patient follow-up was defined from the date of initial referral in one centre to the date of the last visit before the data record or date of death or transplantation. 
Because HDV infection is often clinically asymptomatic, the precise date of contamination was difficult to establish. Moreover, due to the delay in HDV infection diagnosis, some patients already showed hepatic complications before inclusion. For each patient, epidemiological data, such as country of birth and supposed mode of contamination, were recorded. The mode and date of contamination was assumed for sexual, drug use-related or iatrogenic exposure. In endemic countries, contamination was assumed to occur at birth or during childhood. Past and ongoing comorbidities (alcohol, tobacco and drug consumption, arterial hypertension, overweight and diabetes) were noted. Clinical status at baseline and past hepatic complications, when present, were recorded. Hepatic decompensation was defined by the presence of at least one of the following: ascites, hepatic encephalopathy, variceal bleeding.

The date of first positive HBV (positive HBsAg) test was noted, when different from initial referral. When available, biological data recorded at baseline included: complete HBV (HBsAg, HBeAg, anti-HBe Ab, DNA viral load, genotype) and HDV (total and IgM anti-HD Abs, RNA viral load, genotype) profiles; viral coinfections such as hepatitis $\mathrm{C}$ virus (HCV) and human immunodeficiency virus (HIV) with their replicative status; hematological (white cells and platelet count, hemoglobin level, prothrombin time and factor V level) and biochemical evaluation (glycemia, creatinine, total and conjugated bilirubin, AST, ALT, GGT, albumin, gamma-globulin, AFP levels). Baseline or past liver evaluations, were recorded, including liver biopsies, imaging (ultrasonography, MRI, CT-scan), upper gastrointestinal endoscopy, liver stiffness measurements (Fibroscan®), blood tests (Fibrotest $\left.{ }^{\circledR}\right)$. The diagnosis of cirrhosis was based on liver histology $(51.8 \%)$, non-invasive tests $(13.6 \%)$ or because of liver decompensation $(34.5 \%)$. As non-invasive tests have not been validated for HDV, a cut-off > $12 \mathrm{kPa}$ validated for $\mathrm{HBV}$ cirrhosis was used for elastometry according to the EASL guidelines 17. 
New liver events (cirrhosis, hepatic decompensation, HCC) during follow-up were recorded. Liver transplantation (LT), when performed, or death were considered as last visit. For all deceased patients a "likely cause of death" was established.

Anti-viral treatments and viral responses were monitored. Sequential HBV and HDV viral loads and liver function assessments, and complete virological tests at last visit were recorded.

\section{Virological analyses}

Routine HBV and HDV virological parameters, were collected from patient medical files. Because our study extended for many years over several centres, different biological assays were used. All HBV viral load values expressed as copies/mL were converted into IU/mL to allow comparison for longitudinal analyses. Most HDV viral loads were performed at FNRC during the routine patient management, using the FNRC-in-house consensus quantitative RTPCR assay ${ }^{18,19}$. For samples before 2005 , only qualitative results were available. 80 samples were quantified in the Lyon hospital using their in-house assay ${ }^{20}$ with results correlating well with those obtained at the FNRC ${ }^{19}$. Results expressed in copies/mL, were converted in IU/mL according to the WHO international standard and $\log 10$ values were used for longitudinal analyses ${ }^{19}$. Additional virological analyses were performed using the available frozen samples, initially stored at $-80^{\circ} \mathrm{C}$ in the FNRC lab.

HBsAg quantification was performed on frozen samples when the sampling date was close to that of the patient baseline evaluation date $(<1$ year) using the Architect automation platform (Abbott, Rungis, France). Samples were diluted to remain in the quantification range. HBV genotypes determined by direct sequencing or by commercial tests, were recorded or performed subsequently at the FNRC. As HDV is known to suppress HBV viral load ${ }^{21}$, an in-house nested PCR amplifying a region in the POL ORF was used for HBV genotyping. HDV genotypes were determined by direct sequencing and phylogenetic analyses of the $R O$ region of 
the genome, as described ${ }^{15}$. Genotyping was performed on baseline samples if available or on subsequent positive samples.

\section{Statistical analyses}

Descriptive results are expressed as means \pm standard deviations (SD) or median with interquartile range [IQR] for continuous variables and as numbers (percentages) for categoric data. Baseline characteristics were compared between groups using Student's t test or Mann Whitney or Kruskall Wallis test for continuous data, and chi square test or Fisher exact test for qualitative variables.

The occurrence of cirrhosis, liver decompensation, HCC and death or LT were analyzed in different populations. For cirrhosis, the analysis was performed in patients without HCC at baseline; for decompensation, in patients with cirrhosis at baseline or during follow-up; for HCC, in the whole population and for death or LT, in patients without HCC at baseline. For each complication, the time at risk was defined as the time duration between the date of initial referral in one centre to the earliest of the following: date of the studied complication or date of LT, death, or date of the last visit. Separate analyses of prevalent and incident events were performed.

Analysis of features associated with each event was performed in all patients (whatever their HDV replicative status) and separately in patients with positive HDV viral load at inclusion and/or during follow-up.

Due to missing data for most studied variables, multiple imputations by chained equations (MICE) were used by generating 20 imputed datasets, in order to study the robustness of the results based on the available data. The variables with less than $30 \%$ of missing data were imputed. Continuous variables were imputed using predictive mean matching method; for binary variables, logistic regression models; for variables with more than 2 categories: 
multinomial logistic regression models. For each outcome univariate and multivariate logistic regression models were applied for prevalent outcomes and Cox proportional hazards regression method was performed for incident events, first on available data, then on imputed data. Only relevant covariates for each outcome were analyzed in univariate analyses. For both sub analyses, variables with a $\mathrm{p}$ value $<0.20$ in univariate analysis and a rate of missing data $<30 \%$ were tested in multivariate analysis. The final model was determined using a manual backward stepwise elimination until reaching statistical significance for all covariates of the model.

Adjusted Odd Ratios (aOR) and Hazard Ratios (aHR) are presented with their $95 \%$ confidence intervals $(\mathrm{CI})$.

Incidence curves were generated according to the Kaplan-Meier method and compared by logrank test. Variables with a $\mathrm{p} \leq 0.05$ were considered significantly associated with the event. All analyses were performed using Stata V13.0 (Statacorp, College Station, Texas). 


\section{Results}

\section{Patient characteristics at referral}

Among the 4815 consecutive patients recorded in the FNRC database, 1112 HDV infected patients were finally included in the study, based on inclusion criteria. Principal reasons for non-inclusion were inaccessible medical file, incomplete initial evaluation or absence of follow-up visit. Demographical characteristics of the 4815 patients are summarized in supplementary Table 1. Gender and geographical origin were not significantly different between included and non-included patients. Included patients were slightly younger than nonincluded patients (median age $=36.5$ vs 37.6 years, $\mathrm{p}<0.001$ ).

Main clinical and virological characteristics of the cohort are summarized in Table 1. Patients were predominantly male $(68.6 \%)$, the median age at referral being 36.5 [29.9-43.2] years. $36.7 \%$ of the patients were overweight $\left(\mathrm{BMI} \geq 25 \mathrm{~kg} / \mathrm{m}^{2}\right)$ and $9.7 \%$ obese $\left(\mathrm{BMI} \geq 30 \mathrm{~kg} / \mathrm{m}^{2}\right)$; $3.2 \%$ of the cohort population were diabetic, $45.7 \%$ had a history of past or persistent excessive alcohol consumption (>30g/day) and $43.7 \%$ were or have been smokers. Only 150 patients (13.8\%) were native from France, $86.2 \%$ were immigrants, mostly from sub-Saharan Africa $(52.5 \%) ; 21.3 \%$ were from southern and eastern Europe, $6.2 \%$ from northern Africa and the Middle East, 5.9\% from Asia and 0.3\% from South America. Predominant risk factors for HDV transmission were birth in endemic countries $(74.2 \%$ of the cases, probably reflecting maternofetal or intrafamilial contamination), history of intravenous drug use (15.8\%), iatrogenic or nosocomial contamination (5.5\%) and sexual transmission (4.5\%). Viral coinfections were frequent in case of parenteral transmission. Hepatitis C virus (HCV) was present in $24.2 \%$ of the cases, HIV in $19.3 \%$, whereas quadruple HBV-HDV, HCV and HIV coinfection was found in $9 \%$ of the cases.

At referral, 312 patients (28.1\%) had cirrhosis, 407 (36.6\%) had significant or severe fibrosis $(\geq$ F2) and $187(16.8 \%)$ no or minimal fibrosis, information being missing for $18.5 \%$ of the 
patients. 163 patients $(14.7 \%)$ had experienced at least one episode of liver decompensation (ascites, gastrointestinal bleeding and hepatic encephalopathy in 138 (12.5\%), 46 (4.2\%) and 29 (2.6\%) patients, respectively) and $30(2.7 \%)$ had developed HCC. Transaminases were increased in most patients: AST in $77.3 \%$ and ALT in $74.2 \%$ of the cases (median AST and ALT level were 61 [40-101] and 70 [43-121], respectively).

Patient characteristics, classified according to their country of birth, are shown in Table 1. SubSaharan African patients were younger: 33.4 yrs compared to 41.1 yrs and 41.5 yrs for patients from northern Africa and France, respectively $(\mathrm{p}<0.001)$. They displayed lower frequency of excessive alcoholic consumption compared to patients from other geographic areas, and had higher incidence of overweight than European patients. Noteworthy, $75.2 \%$ of native French patients were intravenous drug users (IVDU), sexual transmission being reported in only $15.2 \%$ of the cases. This mode of contamination likely explains the higher rate of HCV and HIV coinfection in this population. By contrast, IVDU were very rare among sub-Saharan African patients.

Cirrhosis at referral was twice less frequent in patients from sub-Saharan Africa than from other countries, independently of age (OR=0.59 [0.34 - 1.02] (Table 2)).

\section{Virological features at referral}

At referral, 748/1112 patients were evaluated for HDV replication and 659 (88.1\%) displayed detectable HDV viral load, with a median value of 161,700 IU/mL [7154-2,606,800]. Among the 748 tested patients at baseline, 89 patients with negative RNA displayed active liver disease. Additional positive PCRs were obtained during follow-up and, globally, HDV genotypes were determined in 837 patients. HDV-1 was predominant (75.9\%), followed by genotypes almost exclusively found in the sub-Saharan area: HDV-5 (17.6\%), HDV-7 (2.9\%), HDV-6 (1.8\%) and HDV-8 (1.6\%). HDV-1 was found in only 55.9\% of the sub-Saharan 
African patients, whereas it represented at least $96 \%$ of the cases in the other ethnic groups. Accordingly, the proportion of other genotypes in this group was higher than average, HDV-5 accounting for $32.7 \%$, HDV-7 for $5.3 \%$, HDV-6 for $3.2 \%$ and HDV-8 for $2.7 \%$ of the patients. Overall, the level of HDV replication was not different in sub-Saharan African compared to non-African patients. However, in the former group the proportion of patients with no detectable replication was larger (16\% versus $3-10 \%$ respectively, $\mathrm{p}<0.001)$ (Table 1).

HBV replication was evaluated in 883/1112 patients: 431 (48.8\%) displayed detectable HBV viral load with a median value of $495 \mathrm{IU} / \mathrm{mL}$ [88-4452]. HBV genotypes were determined in only 260 patients $(23.4 \%)$, due to the inhibition of $\mathrm{HBV}$ replication in most HBV/HDV infected patients. Genotypes E (45\%) and D (39.6\%) were the most prevalent, followed by HBV/A (12.3\%), HBV/G (1.9\%) and HBV/B (1.2\%). HBsAg quantification was performed in 435 patients. Global median HBsAg value was $7320 \mathrm{IU} / \mathrm{mL}$ [2345-14,006], the median values displaying significant differences: from 4206 to $11419 \mathrm{IU} / \mathrm{mL}(\mathrm{p}=0.007)$ in the different goups.

\section{Outcome of patients and occurrence of complications}

The median follow-up from the initial HDV infection diagnosis to the last recorded visit was 3.0 years [0.8-7.2]. At the end of follow-up, 227, 105 and 72 additional patients had developed cirrhosis, liver decompensation and $\mathrm{HCC}$, respectively, corresponding to a total prevalence of $48.8 \%, 24.2 \%$ and $9.2 \%$, respectively. Among new cirrhotic patients, 166/174 (95.4\%) had been classified as having significant or severe fibrosis $(\geq F 2)$ at referral (no initial data available for 53 patients). Noteworthy, cirrhosis was observed both in patients with active HDV infection (positive HDV RNA at referral or during follow-up, $\mathrm{n}=504$ ) and in patients with evidence of past HDV infection (negative HDV RNA, n=35). LT was performed in 153 (13.7\%) patients; the principal cause of transplantation was decompensation (86.9\%), less often $\operatorname{HCC}(23.5 \%)$. 
Overall, 54 patients $(4.9 \%)$ died during the follow-up period, $70.8 \%$ of them due to liverrelated causes. The 5-year risks of cirrhosis, decompensation, HCC, LT or death were 49.4\%, $23.3 \%, 8.2 \%$, and $20.2 \%$, respectively.

Before and during follow-up, a total of 584 patients $(52.5 \%)$ were treated with an interferonbased regimen. The percentage of treated patients was similar according to country of birth (Supplementary table 2). 66.9\% of the patients underwent a single course of IFN therapy and median total duration of treatment was 13.8 months [6.8-26.1] (from 10.0 to 15.5 months according to patient origin).

Among the 415 patients for whom information was available, 165 (39.8\%) were responders, with negative HDV-RNA values persisting more than 6 months after the end of the antiviral therapy (the median time since IFN therapy discontinuation was 33.3 months [11.7-51.0]). Interestingly, HDV viral load at baseline was lower in responders than in non-responders (4.6 vs $5.7 \log \mathrm{IU} / \mathrm{mL}, \mathrm{p}<0.001)$. Overall, African patients exhibited a better response to IFN than non-African patients (46.4\% vs $29.1 \%$, p <0.001) regardless of HDV genotype. HIV coinfection was associated with a worse response to IFN ( $\mathrm{p}=0.036)$.

The impact of IFN therapy on disease outcome was dependent on the response to treatment: the incidence of cirrhosis, hepatic decompensation, death or LT was lower in responders than in non-responder patients $\quad(\mathrm{HR}=0.41, \mathrm{p}=0.012 ; \mathrm{HR}=0.35, \mathrm{p}=0.025 ; \quad \mathrm{HR}=0.15, \mathrm{p}=0.001$, respectively).

\section{Factors associated with occurrence of complications}

Cirrhosis occurrence was associated with the place of birth, independently of age. Sub-Saharan African patients were at lower risk for cirrhosis than European patients $(\mathrm{HR}=0.76, \mathrm{p}=0.04)$, the latter group being at lower risk than northern Africa and Middle East patients $(\mathrm{HR}=1.43$, $\mathrm{p}=0.05$ ). When considering genotype and country of birth together, the incidence of cirrhosis 
was significantly lower for all genotypes in sub-Saharan African patients, $p<0.001$ (Figure 1) but HDV-5 patients displayed a higher risk of cirrhosis than African patients infected with other genotypes. Since alcohol consumption varied according to the geographic origin of the patients and was associated with cirrhosis in the univariate analysis, it was entered into the model for adjustment. The analysis gave similar results with or without alcohol consumption (Supplementary table 3). Older age $(\mathrm{HR}=1.04, \mathrm{p}<0.001)$ and persistent HDV viremia $(\mathrm{HR}=5.75,<0.001)$ were also independent factors associated with cirrhosis (Tables 2 and $\mathbf{3}$, Figure 2A). Similar results were observed in the subgroup of patients with positive HDV viral load at baseline and/or during follow-up (Supplementary table 4).

Factors associated with incident hepatic decompensation were analysed in 375 patients with cirrhosis at baseline or during follow-up and no decompensation before inclusion. Older age $(\mathrm{HR}=1.04, \mathrm{p}=0.003)$, overweight $(\mathrm{HR}=1.88, \mathrm{p}=0.014)$, total bilirubin $>17 \mu \mathrm{mol} / \mathrm{L}(\mathrm{HR}=2.37$ $\mathrm{p}=0.001)$, and low platelet count $([100-150], \mathrm{HR}=2.16, \mathrm{p}=0.004,<100, \mathrm{HR}=4.27, \mathrm{p}<0.001)$ were independent factors associated with decompensation (Table 4). The occurrence of decompensation was also associated with positive HDV-RNA at last evaluation $(\mathrm{HR}=2.57, \mathrm{p}$ $=0.002)($ Figure 2B). Again, similar results were observed in patients with positive HDV viral load at baseline and/or during follow-up (Supplementary table 5).

Older age $(\mathrm{HR}=1.08, \mathrm{p}<0.001)$, past alcohol intake $(\mathrm{HR}=2.39, \mathrm{p}=0.010)$, prothrombin time $\leq 80 \%(\mathrm{HR}=4.15, \mathrm{p}<0.001)$, platelet count $<100(\mathrm{HR}=2.56, \mathrm{p}=0.016)$ and $\mathrm{GGT}>2 \mathrm{~N}(\mathrm{HR}=3.70$, $\mathrm{p}=0.002$ ) were found as independent factors associated with HCC (Table 5). HCC occurrence was also associated with positive HDV-RNA at last evaluation $(\mathrm{HR}=2.14, \mathrm{p}=0.01)$ (Supplementary table 6, Figure 2C). The PAGE-B score was developed to predict HCC occurrence in Caucasian patients with chronic HBV infection, based on age, gender and platelet 
count $^{22}$. When applied to the Deltavir study population, both intermediate (score between 10 and 17) or elevated $(\geq 18)$ scores were associated with increased risk of HCC $(\mathrm{HR}=4.63$ [2.10$10.22]$ and 18.43 [8.16-41.63] respectively, $\mathrm{p}<0.001)$.

Considering the whole study population, except patients with $\mathrm{HCC}$ at baseline, cirrhosis $(\mathrm{HR}=17.0, \mathrm{p}<0.001)$, alcohol intake $(\mathrm{HR}=2.71, \mathrm{p}<0.001)$, prothrombin time $\leq 80 \%(\mathrm{HR}=2.13$, $\mathrm{p}<0.05)$ and low platelet count $\leq 100.000 / \mathrm{mm}^{3}(\mathrm{HR}=3.08, \mathrm{p}=0.001)$ were independent factors associated with death or LT (Table 6), and with persistence of positive HDV RNA at the last evaluation $(\mathrm{HR}=3.30, \mathrm{p}<0.001)$ (Figure 2D). Similar results were observed in patients with positive HDV viral load at baseline and/or during follow-up (Supplementary table 7).

Analyses performed with available data and after multiple imputations, gave similar results with some minor changes. The principal findings of the study were still observed in all analyses, as, for example, the association between place of birth and occurrence of cirrhosis or the persistence of HDV viremia and the incidence of all liver events (Supplementary tables 8 to 14). Factors associated with prevalent events at baseline were similar to those associated with incident events during follow-up.

\section{Discussion}

The Deltavir study, conducted on a cohort of 1112 HDV infected patients, provides a comprehensive picture of HDV infection epidemiology and of clinical outcome in France.

The strengths of our study rely on the consecutive and exhaustive inclusion of HDV infected patients entered in the reference registry established by the FNRC. All patients were followed in academic centres with access to the same clinical management and follow-up, regardless of the patient origin. Moreover, complete virological data were obtained with homogenous standardized techniques. 
In western-Europe countries, HDV infection prevalence is low and has rather been decreasing during the past forty years. However, re-emergence was noted from the year 2000 onwards, mainly due to the increasing number of infected immigrants from endemic regions. The prevalence of HDV infection in each country reflects the origin and the number of these immigrants. HDV infection was estimated at $1.98 \%$ of HBsAg carriers in a survey among French blood donors ${ }^{23}$. More than $85 \%$ of the HDV-infected patients of our study were immigrants from sub-Saharan Africa and from eastern and southern Europe, similar to what was reported in South London ${ }^{24}$. In Germany, HDV infection resurgence was mainly related to immigrants from Eastern Europe, former Soviet Union and Turkey ${ }^{25,}{ }^{26}$. Supporting the significant contribution of immigrants in HDV infection rise, a prevalence of $17 \%$ and $7.5 \%$ of HDV chronic infection was reported in Italy and in Greece among HBsAg positive non-EU citizens, mainly from Eastern Europe ${ }^{27,28}$. In France, during the last 5 years, sub-Saharan immigrants represented the largest proportion of HDV-infected patients (FNRC, unpublished data).

Although likely overestimated (see limitations below) our data corroborate the current view that HDV is responsible for the most severe form of chronic viral hepatitis. At first referral, $30 \%$ of the study participants had cirrhosis, half of them having experienced one or more episodes of hepatic decompensation. At the end of the follow-up, half of the patients had cirrhosis and $25 \%$ liver decompensation. Previous studies in European centres also reported cirrhosis in more than $30 \%$ of the cases ${ }^{6,729}$. In our cohort we established that the 5 -year risk of hepatic decompensation in case of HBV-HDV infection was much higher than in HBV monoinfected patients of the French Cirvir cohort $(23.3 \% \text { vs } 5.6 \%)^{30}$. The 5-year risk of HCC occurrence was instead equivalent $(8.2 \%$ vs $8.6 \%)$ indicating that HDV has no additional role in liver carcinogenesis compared to that of HBV alone, as recently suggested ${ }^{22,29}$. 
It has not been established yet whether the overall worse prognosis in HDV-infected patients is associated with any HDV genotype. Although previous reports suggested that some HDV genotypes might cause more severe liver disease than others, the size of the cohorts was generally small and the diversity of HDV limited to a few genotypes with only one or two predominant genotypes. HDV-1 was associated with poorer outcome (cirrhosis, HCC or mortality) than genotype HDV-2 in Taiwanese studies ${ }^{31-33}$. In Japan, Watanabe et al. reported that the HDV-4 subgroup caused more severe liver involvement than the HDV-2 subgroup ${ }^{34}$. The overall size and the large heterogeneity of the HDV-infected populations of our study, provided the opportunity to compare the clinical progression of HDV infection among various ethnic groups infected with different HDV genotypes. We could determine, for instance, that cirrhosis was less frequent in sub-Saharan African than in European patients. The only large international study available so far, in which the severity of liver disease of HDV-infected patients was compared in different countries, could not provide this information since no data were available for patients born in Africa ${ }^{35}$. Of note, comorbidities may be confounding factors but this finding persisted after adjustment for alcohol consumption or the presence of metabolic syndrome. African patients were younger on average than Europeans and were probably mostly infected by HDV in the perinatal period or during childhood. However, the higher rate of cirrhosis in European patients was also suggested by a study on a small-size British cohort, in which the median age was equivalent for African and non-African patients ${ }^{36}$. In the British cohort, African patients, who were exclusively infected by HDV-5, displayed a better prognosis than European patients, mostly infected with HDV-1 ${ }^{36}$, leaving open the question of the respective role of the HDV genotype versus patient genetic background and/or environmental factors in the severity of the disease. The analysis of the African patients of our cohort, who were infected with a larger variety of viral strains (HDV-1 of different subtypes and HDV-5 to HDV-8), showed that among them cirrhosis occurred significantly less often in HDV-1- than in 
HDV-5-infection. The HDV-5 genotype appears more fibrogenic than HDV-1 in sub-Saharan African patients, but less than HDV-1 in non-African patients. This observation supports the hypothesis that the HDV genotype contributes to the severity of liver involvement. Moreover, sequence differences between African HDV-1 strains and European/Asian HDV-1 strains, ${ }^{16}$ might also determine variable rates of fibrosis progression, the former being less aggressive that the latter. Unfortunately, due to partial sequencing, subgenotype analysis was not available in the Deltavir study.

We analyzed the HDV replication level and its clinical significance for the various infecting genotypes. Contrasting with other studies affected by the very large interassay variability among HDV RNA PCRs ${ }^{19,37}$, almost all samples in our study were analysed with the FNRC consensus “in-house” quantitative RT-PCR assay, which can quantify RNA load for almost all HDV strains ${ }^{18}$. Noteworthy, our data showed a higher rate of non-replicative (i.e. past) HDV infection in the group of African patients. This fact could contribute to the reduced aggressivity of the HDV infection and the lower rate of cirrhosis in these patients. The influence of HDV genotype on the occurrence of cirrhosis persisted when analysis were conducted only in patients with positive HDV RNA.

Overall, in our study, African patients displayed a significant better response to interferon therapy than non-African patients $(46.3 \%$ vs $29.1 \%$ respectively), the latter percentage being similar to that reported by Wedemeyer in a smaller (but comparable in terms of diversity) population of non African-patients ${ }^{38}$. A better response to IFN therapy in African patients infected with HDV-5 compared to European patients infected with HDV-1 was also found in a British cohort $(62 \% \text { vs } 18 \%, \mathrm{p}=0.047)^{39}$. In our cohort, HDV viral load at baseline was significantly lower in responders than in non-responders. As for the severity of liver involvement, the superior response to treatment of African patients is likely attributable to the genotype and HDV viremia level rather than to the genetic background of the patients. Indeed, 
African American patients infected by $\mathrm{HCV}$ are known to be rather less responsive to interferon therapy than Caucasian patients ${ }^{40}$ in part because of the presence of a particular $I L 28 B$ gene polymorphism inherited from African ancesters ${ }^{41}$. So far, a single Brazilian study reported an unusually high response rate (>95\%) to Peg IFN - entecavir combination in nonEuropean HDV-3-infected patients, suggesting that this particular genotype might represent an "easy-to-treat" variant compared to $\mathrm{HDV}-1^{42}$. We cannot exclude that environmental factors could specifically influence the immune response to HDV during chronic infection, as more generally reported in healthy subjects ${ }^{43}$. A prospective study with a detailed survey for environmental factors and a comprehensive investigation of the immune response will be of great interest in this context.

Here, HDV replication was monitored during patient follow-up: persistent replicative infection was associated with significantly increased risk of all hepatic complications with the highest aHR (5.75) for cirrhosis risk. Previous reports had suggested the same correlation: patients with sustained virologic response were less likely to develop complications than patients with persistent HDV replication ${ }^{44}$, and clearance of HDV RNA was identified as an independent parameter associated with favourable outcome ${ }^{29}$. In $\mathrm{HBV}$ and $\mathrm{HCV}$ monoinfections, persistence of viral replication is also associated with increased frequency of hepatic decompensation and mortality ${ }^{45}$.

Other risk factors for severe hepatic involvement appear to be shared with hepatitis B and C. Older age, low prothrombin time and low platelet count were associated with the occurrence of hepatic decompensation and HCC. Metabolic factors such as alcohol consumption and obesity were independent factors associated with HCC.

Although our cohort is the largest at the national level, this study has some limitations. Since data were collected retrospectively, only patients with available files and homogenous data were included in the study, excluding most patients followed by non-hospital practitioners. 
Consequently, the overall disease severity is likely over-estimated respective to the actual condition in the French population. Furthermore, because of the retrospective data collection, some data were missing, although statistical methods using multiple imputations allowed us to confirm the robustness of results obtained with the "available data".

In conclusion, HDV infection in France is associated with enhanced progression to cirrhosis and decompensation compared to HBV monoinfection. Persistent HDV viremia is the strongest predictor factor for cirrhosis, liver decompensation, $\mathrm{HCC}$ and death. Owing to the diversity of geographical origin and HDV genotypes among the patients of our cohort, we could establish that severity of liver involvement and response to treatment are dependent on birth origin and HDV genotype.

\section{References}

[1] Schweitzer A, Horn J, Mikolajczyk RT, Krause G, Ott JJ. Estimations of worldwide prevalence of chronic hepatitis B virus infection: a systematic review of data published between 1965 and 2013. Lancet 2015;386:1546-55.

[2] Chen HY, Shen DT, Ji DZ, Han PC, Zhang WM, Ma JF, et al. Prevalence and burden of hepatitis D virus infection in the global population: a systematic review and metaanalysis. Gut 2018.

[3] Fattovich G, Boscaro S, Noventa F, Pornaro E, Stenico D, A. A, et al. Influence of hepatitis delta virus infection on progression to cirrhosis in chronic hepatitis type B. J Infect Dis 1987;155:931-935.

[4] Yurdaydin C, Idilman R, Bozkaya H, Bozdayi AM. Natural history and treatment of chronic delta hepatitis. J Viral Hepat 2010;17:749-56. 
[5] Romeo R, Del Ninno E, Rumi M, Russo A, Sangiovanni A, de Franchis R, et al. A 28year study of the course of hepatitis Delta infection: a risk factor for cirrhosis and hepatocellular carcinoma. Gastroenterology 2009;136:1629-38.

[6] Niro GA, Smedile A, Ippolito AM, Ciancio A, Fontana R, Olivero A, et al. Outcome of chronic delta hepatitis in Italy: a long-term cohort study. J Hepatol 2010;53:834-40.

[7] Buti M, Homs M, Rodriguez-Frias F, Funalleras G, Jardi R, Sauleda S, et al. Clinical outcome of acute and chronic hepatitis delta over time: a long-term follow-up study. $\mathrm{J}$ Viral Hepat 2011;18:434-42.

[8] Fattovich G, Giustina G, Christensen E, Pantalena M, Zagni I, Realdi G, et al. Influence of hepatitis delta virus infection on morbidity and mortality in compensated cirrhosis type B. The European Concerted Action on Viral Hepatitis (Eurohep). Gut 2000;46:420-6.

[9] Ji J, Sundquist K, Sundquist J. A population-based study of hepatitis D virus as potential risk factor for hepatocellular carcinoma. J Natl Cancer Inst 2012;104:790-2.

[10] Wedemeyer H, Yurdaydin C, Hardtke S, Caruntu FA, Curescu MG, Yalcin K, et al. Peginterferon alfa-2a plus tenofovir disoproxil fumarate for hepatitis D (HIDIT-II): a randomised, placebo controlled, phase 2 trial. Lancet Infect Dis 2019;19:275-286.

[11] Braga WS, de Oliveira CM, de Araujo JR, Castilho Mda C, Rocha JM, Gimaque JB, et al. Chronic HDV/HBV co-infection: predictors of disease stage---a case series of HDV-3 patients. J Hepatol 2014;61:1205-11.

[12] Casey JL, Brown TL, Colan EJ, Wignall FS, Gerin JL. A genotype of hepatitis D virus that occurs in northern South America. Proc Natl Acad Sci U S A 1993;90:9016-20.

[13] Casey JL, Niro GA, Engle RE, Vega A, Gomez H, McCarthy M, et al. Hepatitis B virus (HBV)/hepatitis D virus (HDV) coinfection in outbreaks of acute hepatitis in the 
Peruvian Amazon basin: the roles of HDV genotype III and HBV genotype F. J Infect Dis 1996;174:920-6.

[14] Radjef N, Gordien E, Ivaniushina V, Gault E, Anais P, Drugan T, et al. Molecular phylogenetic analyses indicate a wide and ancient radiation of African hepatitis delta virus, suggesting a deltavirus genus of at least seven major clades. J Virol 2004;78:2537-44.

[15] Le Gal F, Gault E, Ripault MP, Serpaggi J, Trinchet JC, Gordien E, et al. Eighth major clade for hepatitis delta virus. Emerg Infect Dis 2006;12:1447-50.

[16] Le Gal FL, Brichler S, Drugan T, Alloui C, Roulot D, Pawlotsky JM, et al. Genetic diversity and worldwide distribution of the deltavirus genus: A study of 2,152 clinical strains. 2017;66:1826-1841.

[17] European Association for Study of L, Asociacion Latinoamericana para el Estudio del H. EASL-ALEH Clinical Practice Guidelines: Non-invasive tests for evaluation of liver disease severity and prognosis. J Hepatol 2015;63:237-64.

[18] Le Gal F, Gordien E, Affolabi D, Hanslik T, Alloui C, Deny P, et al. Quantification of hepatitis delta virus RNA in serum by consensus real-time PCR indicates different patterns of virological response to interferon therapy in chronically infected patients. $\mathbf{J}$ Clin Microbiol 2005;43:2363-9.

[19] Le Gal F, Brichler S, Sahli R, Chevret S, Gordien E. First international external quality assessment for hepatitis delta virus RNA quantification in plasma. Hepatology 2016;64:1483-1494.

[20] Scholtes C, Icard V, Amiri M, Chevallier-Queyron P, Trabaud MA, Ramiere C, et al. Standardized one-step real-time reverse transcription-PCR assay for universal detection and quantification of hepatitis delta virus from clinical samples in the presence of a heterologous internal-control RNA. J Clin Microbiol 2012;50:2126-8. 
[21] Williams V, Brichler S, Radjef N, Lebon P, Goffard A, Hober D, et al. Hepatitis delta virus proteins repress hepatitis $B$ virus enhancers and activate the alpha/beta interferon-inducible MxA gene. J Gen Virol 2009;90:2759-67.

[22] Papatheodoridis G, Dalekos G, Sypsa V, Yurdaydin C, Buti M, Goulis J, et al. PAGE$\mathrm{B}$ predicts the risk of developing hepatocellular carcinoma in Caucasians with chronic hepatitis B on 5-year antiviral therapy. J Hepatol 2016;64:800-6.

[23] Servant-Delmas A, Le Gal F, Gallian P, Gordien E, Laperche S. Increasing prevalence of HDV/HBV infection over 15 years in France. J Clin Virol 2014;59:126-8.

[24] Cross TJ, Rizzi P, Horner M, Jolly A, Hussain MJ, Smith HM, et al. The increasing prevalence of hepatitis delta virus (HDV) infection in South London. J Med Virol 2008;80:277-82.

[25] Wedemeyer H, Heidrich B, Manns MP. Hepatitis D virus infection--not a vanishing disease in Europe! Hepatology 2007;45:1331-2; author reply 1332-3.

[26] Reinheimer C, Doerr HW, Berger A. Hepatitis delta: on soft paws across Germany. Infection 2012;40:621-5.

[27] Piccolo P, Lenci I, Telesca C, Di Paolo D, Bandiera F, De Melia L, et al. Patterns of chronic hepatitis B in Central Italy: a cross-sectional study. Eur J Public Health 2010;20:711-3.

[28] Manesis EK, Vourli G, Dalekos G, Vasiliadis T, Manolaki N, Hounta A, et al. Prevalence and clinical course of hepatitis delta infection in Greece: a 13-year prospective study. J Hepatol 2013;59:949-56.

[29] Wranke A, Serrano BC, Heidrich B, Kirschner J, Bremer B, Lehmann P, et al. Antiviral treatment and liver-related complications in hepatitis delta. Hepatology $2017 ; 65: 414-425$. 
[30] Brichler S, Nahon P, Zoulim F, Layese R, Bourcier V, Audureau E, et al. Nonvirological factors are drivers of hepatocellular carcinoma in virosuppressed hepatitis B cirrhosis: Results of ANRS CO12 CirVir cohort. J Viral Hepat 2019;26:384-396.

[31] Hsu SC, Syu WJ, Sheen IJ, Liu HT, Jeng KS, Wu JC. Varied assembly and RNA editing efficiencies between genotypes I and II hepatitis D virus and their implications. Hepatology 2002;35:665-72.

[32] Wu JC, Choo KB, Chen CM, Chen TZ, Huo TI, Lee SD. Genotyping of hepatitis D virus by restriction-fragment length polymorphism and relation to outcome of hepatitis D. Lancet 1995;346:939-41.

[33] Su CW, Huang YH, Huo TI, Shih HH, Sheen IJ, Chen SW, et al. Genotypes and viremia of hepatitis B and D viruses are associated with outcomes of chronic hepatitis D patients. Gastroenterology 2006;130:1625-35.

[34] Watanabe H, Nagayama K, Enomoto N, Chinzei R, Yamashiro T, Izumi N, et al. Chronic hepatitis delta virus infection with genotype IIb variant is correlated with progressive liver disease. J Gen Virol 2003;84:3275-89.

[35] Wranke A, Pinheiro Borzacov LM, Parana R, Lobato C, Hamid S, Ceausu E, et al. Clinical and virological heterogeneity of hepatitis delta in different regions worldwide: The Hepatitis Delta International Network (HDIN). Liver Int 2017;38:842-850.

[36] Spaan M, Carey I, Wang B, Shang D, Horner M, Bruce M, et al. Outcome in chronic hepatitis delta: differences between African and non-African patients. J Hepatol 2017; Volume 66:s255-s256.

[37] Brichler S, Le Gal F, Neri-Pinto F, Mansour W, Roulot D, Laperche S, et al. Serological and molecular diagnosis of hepatitis delta virus infection: results of a French national quality control study. J Clin Microbiol 2014;52:1694-7. 
[38] Wedemeyer H, Yurdaydin C, Dalekos GN, Erhardt A, Cakaloglu Y, Degertekin H, et al. Peginterferon plus adefovir versus either drug alone for hepatitis delta. N Engl J Med 2011;364:322-31.

[39] Spaan M, Bruce M, Shang D, Horner M, Dusheiko G, Carey I, et al. Patients with genotype 5 hepatitis delta infection have a favourable outcome of disease and better treatment response to pegylated interferon therapy compared to genotype 1 patients. $\mathrm{J}$ Hepatol 2018; Volume 68:s493.

[40] Conjeevaram HS, Fried MW, Jeffers LJ, Terrault NA, Wiley-Lucas TE, Afdhal N, et al. Peginterferon and ribavirin treatment in African American and Caucasian American patients with hepatitis C genotype 1. Gastroenterology 2006;131:470-7.

[41] Thomas DL, Thio CL, Martin MP, Qi Y, Ge D, O'Huigin C, et al. Genetic variation in IL28B and spontaneous clearance of hepatitis C virus. Nature 2009;461:798-801.

[42] Borzacov LM, de Figueiredo Nicolete LD, Souza LF, Dos Santos AO, Vieira DS, Salcedo JM. Treatment of hepatitis delta virus genotype 3 infection with peginterferon and entecavir. Int J Infect Dis 2016;46:82-8.

[43] Aguirre-Gamboa R, Joosten I, Urbano PCM, van der Molen RG, van Rijssen E, van Cranenbroek B, et al. Differential Effects of Environmental and Genetic Factors on T and B Cell Immune Traits. Cell Rep 2016;17:2474-2487.

[44] Yurdaydin C, Keskin O, Kalkan C, Karakaya F, Caliskan A, Kabacam G, et al. Interferon Treatment Duration in Patients With Chronic Delta Hepatitis and its Effect on the Natural Course of the Disease. J Infect Dis 2018;217:1184-1192.

[45] Nahon P, Bourcier V, Layese R, Audureau E, Cagnot C, Marcellin P, et al. Eradication of Hepatitis C Virus Infection in Patients With Cirrhosis Reduces Risk of Liver and Non-Liver Complications. Gastroenterology 2017;152:142-156 e2. 


\section{Figure legends}

Figure 1. Association of HDV genotypes and place of birth with cirrhosis occurrence

In African patients, the 10-year cumulative incidence of cirrhosis was significantly lower than in non-African patients: $26.4 \%$ for patients infected with African genotypes 1, 6, 7 and 8 and $40.3 \%$ for infection with genotype 5 vs $53.7 \%(\mathrm{p}=0.002)$ for patients infected with non-African genotype 1 (log-rank test).

Figure 2. Incidence of hepatic complications and survival without liver transplantation according to persistent HDV viremia before endpoint

(A): the 10-year cumulative incidence of cirrhosis was $12.2 \%$ in patients who achieved HDV RNA negativation vs $51.9 \%$ in patients who remained HDV RNA positive $(\mathrm{p}<0.001)$.

(B): the 10-year cumulative incidence of hepatic decompensation was $14.5 \%$ in patients who achieved HDV RNA negativation vs $38.9 \%$ in patients who remained HDV RNA positive $(\mathrm{p}<0.001)$. (C): the 10-year cumulative incidence of hepatocellular carcinoma was $8.0 \%$ in patients who achieved HDV RNA negativation vs $12.9 \%$ in patients who remained HDV RNA positive $(\mathrm{p}=0.006)$. (D): the survival without liver transplantation at 10 years was $91.1 \%$ in patients who achieved HDV RNA negativation vs $75.3 \%$ in patients who remained HDV RNA positive $(\mathrm{p}<0.001)($ log-rank test). 
Table 1 : At referral characteristics of the overall population, and according to birth country

\begin{tabular}{|c|c|c|c|c|c|c|c|c|}
\hline & $\begin{array}{l}\text { Number of } \\
\text { subjects } \\
\text { tested }\end{array}$ & $\begin{array}{l}\text { Overall } \\
\mathrm{n}=1112\end{array}$ & $\begin{array}{l}\text { France } \\
n=150\end{array}$ & $\begin{array}{l}\text { Europe (except } \\
\text { France)* } \\
\mathbf{n = 2 3 2}\end{array}$ & $\begin{array}{l}\text { Northern Africa + } \\
\text { Middle East } \\
\mathrm{n}=68\end{array}$ & $\begin{array}{l}\text { Subsah. Africa } \\
\mathrm{n}=572\end{array}$ & $\begin{array}{l}\text { Asia } \\
\mathrm{n}=65\end{array}$ & P-value \\
\hline Place of birth & 1090 & & & & & & & \\
\hline France & & $150(13.8)$ & & & & & & \\
\hline Europe (except France) * & & $232(21.3)$ & & & & & & \\
\hline Northern Africa + Middle East & & $68(6.2)$ & & & & & & \\
\hline Subsaharan Africa & & $572(52.5)$ & & & & & & \\
\hline Asia & & $65(5.9)$ & & & & & & \\
\hline South America & & $3(0.3)$ & & & 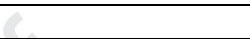 & & & \\
\hline Male gender & 1112 & 763 (68.6) & $135(90.0)$ & $163(70.3)$ & $62(91.2)$ & $346(60.5)$ & $37(56.9)$ & $<0.001^{\mathrm{a}}$ \\
\hline Age (years) ** & 1112 & $36.5[29.9-43.2]$ & $41.5[36.8-46.4]$ & $36.9[30.1-45.1]$ & $41.1[35.2-46.0]$ & $33.4[28.3-40.4]$ & $39.9[31.6-45.5]$ & $<0.001^{\mathrm{c}}$ \\
\hline Route of transmission & 1046 & & & & 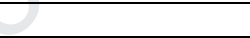 & & & $<0.001^{\mathrm{a}}$ \\
\hline Birth in endemic country & & $776(74.2)$ & $3(2.4)$ & $163(74.1)$ & $42(71.2)$ & $518(91.8)$ & $50(79.4)$ & \\
\hline Nosocomial/iatrogenic & & $58(5.5)$ & $9(7.2)$ & $15(6.8)$ & $2(3.4)$ & $24(4.3)$ & $5(7.9)$ & \\
\hline Sexual & & $47(4.5)$ & $19(15.2)$ & $4(1.8)$ & $3(5.1)$ & $15(2.7)$ & $2(3.2)$ & \\
\hline IVDU & & $165(15.8)$ & $94(75.2)$ & $38(17.3)$ & $12(20.3)$ & $7(1.2)$ & $6(9.5)$ & \\
\hline Alcohol & 867 & & & 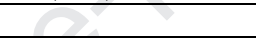 & & & & $<0.001^{\mathrm{a}}$ \\
\hline Past/ongoing & & $396(45.7)$ & $99(76.1)$ & $73(47.7)$ & $29(53.7)$ & $170(32.2)$ & $22(42.3)$ & \\
\hline Tobacco consumption & 824 & & & +2 & & & & $<0.001^{\mathrm{a}}$ \\
\hline Past/ongoing & & $350(42.5)$ & $107(85.6)$ & $102(60.7)$ & $34(63.0)$ & $97(22.2)$ & $18(40.0)$ & \\
\hline Overweight (BMI $\left.\geq 25 \mathrm{~kg} / \mathrm{m}^{2}\right)$ & 773 & $284(36.7)$ & $17(15.3)$ & $55(36.7)$ & $21(44.7)$ & $169(41.7)$ & $18(38.3)$ & $<0.001^{\mathrm{a}}$ \\
\hline Diabetes & 1017 & $33(3.2)$ & $1(0.7)$ & $9(4.1)$ & $4(6.3)$ & $15(2.9)$ & $3(5.5)$ & $0.10^{\mathrm{b}}$ \\
\hline Arterial hypertension & 1020 & $97(9.5)$ & $8(5.8)$ & $8(3.7)$ & $3(4.7)$ & $70(13.4)$ & $6(10.9)$ & $<0.001^{\mathrm{a}}$ \\
\hline HDV genotype $* * *$ & 837 & & 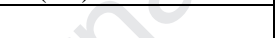 & & & & & $<0.001^{\mathrm{a}}$ \\
\hline 1 & & $635(75.9)$ & $121(98.4)$ & $160(98.2)$ & $51(100)$ & $245(55.9)$ & $48(96.0)$ & \\
\hline 2 & & $2(0.2)$ & 0 & 0 & 0 & $1(0.2)$ & $1(0.2)$ & \\
\hline 3 & & $1(0.1)$ & 0 & $1(0.6)$ & 0 & 0 & 0 & \\
\hline 5 & & 147 (17.6) & $2(1.6)$ & $1(0.6)$ & 0 & $143(32.7)$ & 0 & \\
\hline 6 & & $15(1.8)$ & 0 & $1(0.6)$ & 0 & $14(3.2)$ & 0 & \\
\hline 7 & & $24(2.9)$ & 0 & 0 & 0 & $23(5.3)$ & 0 & \\
\hline 8 & & $13(1.6)$ & 0 & 0 & 0 & $12(2.7)$ & $1(2.0)$ & \\
\hline Positive HDV VL & 748 & $659(88.1)$ & $92(90.2)$ & $135(97.1)$ & $44(89.8)$ & $330(84.0)$ & $47(92.2)$ & $<0.001^{\mathrm{a}}$ \\
\hline HDV viral load (IU/mL) (only +)** & 456 & $\begin{array}{l}161700[7154- \\
2606800]\end{array}$ & $\begin{array}{l}258720[3517- \\
2256254]\end{array}$ & $\begin{array}{l}266765[12456- \\
4656568]\end{array}$ & $\begin{array}{l}158760[26656- \\
1921584]\end{array}$ & $\begin{array}{l}115640[4557- \\
1766971]\end{array}$ & $\begin{array}{l}213928[11172- \\
2864834]\end{array}$ & $0.27^{\mathrm{c}}$ \\
\hline HBsAg (IU/ml) quantification *** & 435 & $7320[2345-14006]$ & 5964 [1203-13347] & $11419[3738-19602]$ & 4206 [1906-12776] & $6368[2103-11735]$ & $10794[3778-14972]$ & $0.007^{\mathrm{c}}$ \\
\hline Positive HBeAg & 1000 & $158(15.8)$ & $28(21.1)$ & $31(15.2)$ & $8(13.3)$ & $74(14.2)$ & $13(21.3)$ & $0.24^{\mathrm{a}}$ \\
\hline Positive HBV viral load & 883 & $431(48.8)$ & $44(40.4)$ & $82(47.1)$ & $28(52.8)$ & $234(49.3)$ & $34(58.6)$ & $0.21^{\mathrm{a}}$ \\
\hline HBV viral load (IU/mL) (only +)** & 396 & $495.0[88.0-4452.0]$ & $694.0[129-13000]$ & 305.5 [62-2645] & $1658.5[118-4274]$ & $400.0[82-4435]$ & 784.0 [194-12834] & $0.39^{\mathrm{c}}$ \\
\hline \multicolumn{9}{|l|}{ Anti-HCV status } \\
\hline Positive antibodies & 955 & $231(24.2)$ & $105(77.8)$ & $60(29.4)$ & $16(25.8)$ & $28(5.8)$ & $12(23.1)$ & $<0.001^{\mathrm{a}}$ \\
\hline $\begin{array}{l}\text { Positive viremia } \\
\end{array}$ & 206 & $35(17.0)$ & $15(16.0)$ & $9(17.0)$ & $1(6.3)$ & $7(31.8)$ & $1(8.3)$ & $0.31^{\mathrm{b}}$ \\
\hline \multicolumn{9}{|l|}{ Anti-HIV status } \\
\hline Positive antibodies & 931 & $180(19.3)$ & $65(47.8)$ & $12(6.3)$ & $11(19.3)$ & $83(17.4)$ & $2(4.1)$ & $<0.001^{\mathrm{a}}$ \\
\hline Positive viremia & 160 & $96(60.0)$ & $27(48.2)$ & $10(90.9)$ & $7(63.6)$ & $45(61.6)$ & $1(50.0)$ & $0.070^{\mathrm{b}}$ \\
\hline Cirrhosis & 1105 & $312(28.2)$ & $56(37.3)$ & $110(47.6)$ & $30(44.1)$ & $103(18.1)$ & $8(12.7)$ & $<0.001^{\mathrm{a}}$ \\
\hline Decompensation & 1106 & $163(14.7)$ & $31(20.7)$ & $68(29.4)$ & $17(25.4)$ & $41(7.2)$ & $3(4.7)$ & $<0.001^{\mathrm{b}}$ \\
\hline HCC & 1106 & $30(2.7)$ & $3(2.0)$ & $7(3.0)$ & $4(5.9)$ & $15(2.6)$ & 0 & $0.33^{\mathrm{b}}$ \\
\hline
\end{tabular}

*Including 1 USA patient; ** median [IQR] $* * *$ determined at referral or during follow-up

${ }^{a}$ Chi-square test; ${ }^{\mathrm{b}}$ Fisher exact test; ${ }^{\mathrm{c}}$ Kruskal-Wallis test 


\section{Table 2: Factors associated with prevalent cirrhosis: univariate and multivariate analysis (Logistic regression method)}

\begin{tabular}{|c|c|c|c|c|c|c|c|c|c|}
\hline \multirow[b]{2}{*}{ Features } & \multirow[b]{2}{*}{$\begin{array}{c}\text { Number of } \\
\text { patients }\end{array}$} & \multirow[b]{2}{*}{$\begin{array}{c}\text { Absence of } \\
\text { cirrhosis at } \\
\text { baseline } \\
\text { n=793 }\end{array}$} & \multirow[b]{2}{*}{$\begin{array}{c}\text { Presence of } \\
\text { cirrhosis at } \\
\text { baseline } \\
n=312\end{array}$} & \multicolumn{3}{|c|}{ Univariate analysis } & \multicolumn{3}{|c|}{ Multivariate analysis } \\
\hline & & & & OR & $95 \%$ OR CI & P-value & OR & $95 \%$ OR CI & P-value \\
\hline Age at patient care (years) & 1105 & $34.5[29.0-40.8]$ & $41.5[34.5-47.7]$ & 1.07 & {$[1.06 ; 1.09]$} & $<0.001$ & 1.06 & {$[1.04 ; 1.09]$} & $<0.001$ \\
\hline & & $35.0 \pm 9.2$ & $41.4 \pm 10.2$ & & & & & & \\
\hline Gender & 1105 & & & & & & & & \\
\hline Male & & $522(65.8)$ & $239(76.6)$ & 1.70 & {$[1.26 ; 2.30]$} & 0.001 & 1.64 & {$[1.04 ; 2.60]$} & 0.034 \\
\hline Female & & $271(34.2)$ & $73(23.4)$ & Ref & 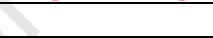 & & Ref & & \\
\hline Diabetes & 1013 & $17(2.4)$ & $16(5.4)$ & 2.32 & {$[1.16 ; 4.65]$} & 0.018 & & & \\
\hline Obesity/Overweight & 963 & $195(28.3)$ & $90(33.0)$ & 1.25 & {$[0.92 ; 1.69]$} & 0.150 & & & \\
\hline Arterial hypertension & 1015 & $59(8.3)$ & $37(12.3)$ & 1.56 & {$[1.01 ; 2.40]$} & 0.046 & & & \\
\hline Alcohol intake & 862 & & (2) (1- & 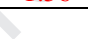 & & $<0.001$ & & & \\
\hline Never & & $343(55.6)$ & $124(50.6)$ & Ref & & & & & \\
\hline Past & & $70(11.3)$ & $68(27.8)$ & 2.69 & {$[1.82 ; 3.98]$} & $<0.001$ & & & \\
\hline Ongoing & & $204(33.1)$ & $53(21.6)$ & 0.72 & {$[0.50 ; 1.04]$} & 0.076 & & & \\
\hline Tobacco intake & 820 & & $x_{2}$ & & & $<0.001$ & & & \\
\hline Never & & $261(62.9)$ & $110(44.7)$ & Ref & & & & & \\
\hline Past & & $54(9.4)$ & $53(21.5)$ & 3.22 & {$[2.08 ; 4.98]$} & $<0.001$ & & & \\
\hline Ongoing & & $159(27.7)$ & $83(33.7)$ & 1.71 & {$[1.22 ; 2.41]$} & 0.002 & & & \\
\hline IV drug use & 783 & $118(20.6)$ & $57(27.1)$ & 1.44 & {$[0.99 ; 2.07]$} & 0.052 & & & \\
\hline Place of birth & 1084 & 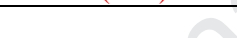 & 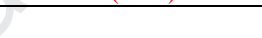 & & & $<0.001$ & & & $<0.001$ \\
\hline France & & $94(12.1)$ & $56(18.1)$ & Ref & & & Ref & & \\
\hline Europe (except France) & & $121(15.6)$ & $110(35.6)$ & 1.53 & {$[1.00 ; 2.32]$} & 0.048 & 1.74 & {$[0.94 ; 3.24]$} & 0.078 \\
\hline Northern Africa + Middle East & & $38(4.9)$ & $30(9.7)$ & 1.33 & {$[0.74 ; 2.37]$} & 0.343 & 1.45 & {$[0.67 ; 3.16]$} & 0.347 \\
\hline Subsaharan Africa & & $466(60.1)$ & $103(33.3)$ & 0.37 & {$[0.25 ; 0.55]$} & $<0.001$ & 0.59 & {$[0.34 ; 1.02]$} & 0.038 \\
\hline Asia & & $55(7.1)$ & $8(2.6)$ & 0.24 & {$[0.11 ; 0.55]$} & 0.001 & 0.29 & {$[0.11 ; 0.82]$} & 0.019 \\
\hline Anti-HCV antibodies & 951 & 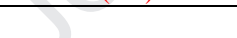 & & & & & & & \\
\hline Negative & & $530(78.4)$ & $193(70.2)$ & Ref & & & & & \\
\hline Positive & & $146(21.6)$ & $82(29.8)$ & 1.54 & {$[1.12 ; 2.12]$} & 0.007 & & & \\
\hline Anti-HIV antibodies & 927 & & & & & & & & \\
\hline Negative & & $526(80.2)$ & $221(81.6)$ & Ref & & & & & \\
\hline Positive & & $130(19.8)$ & $50(18.4)$ & 0.92 & {$[0.64 ; 1.31]$} & 0.632 & & & \\
\hline HBV viral load (baseline) & 877 & & & & & & & & \\
\hline Negative & & $316(48.5)$ & $135(60.0)$ & Ref & & & Ref & & \\
\hline Positive & & $336(51.5)$ & $90(40.0)$ & 0.63 & {$[0.46 ; 0.85]$} & 0.003 & 0.59 & {$[0.40 ; 0.86]$} & 0.006 \\
\hline HDV viral load (baseline) & 743 & & & & & & & & \\
\hline Negative & & $74(13.4)$ & $15(7.8)$ & Ref & & & & & \\
\hline Positive & & $477(86.6)$ & $177(92.2)$ & 1.83 & {$[1.02 ; 3.27]$} & 0.041 & & & \\
\hline HDV Genotype & 833 & & & & & $<0.001$ & & & \\
\hline 1 Non Afr & & $244(39.9)$ & $138(62.4)$ & Ref & & & & & \\
\hline 1 Afr & & $202(33.0)$ & $41(18.6)$ & 0.36 & {$[0.24 ; 0.53]$} & $<0.001$ & & & \\
\hline 5 & & $116(18.9)$ & $31(14.0)$ & 0.47 & {$[0.30 ; 0.74]$} & 0.001 & & & \\
\hline Other & & $50(8.2)$ & $11(5.0)$ & 0.39 & {$[0.20 ; 0.77]$} & 0.007 & & & \\
\hline
\end{tabular}


Table 3: Factors associated with the incidence of cirrhosis: univariate and multivariate analysis (Cox proportional hazards regression method)

\begin{tabular}{|c|c|c|c|c|c|c|c|c|c|}
\hline & & & & & Univariate ana & & & ultivariate ana & \\
\hline Features & $\begin{array}{c}\text { Number } \\
\text { of } \\
\text { patients }\end{array}$ & $\begin{array}{c}\text { No cirrhosis } \\
n=563\end{array}$ & $\begin{array}{c}\text { Cirrhosis } \\
\text { n=226 }\end{array}$ & HR & $95 \%$ HR CI & P-value & HR & $95 \%$ HR CI & P-value \\
\hline Age at patient care (years) & 789 & $33.3[28.5-40.3]$ & $36.6[30.0-42.5]$ & 1.03 & {$[1.02 ; 1.05]$} & $<0.001$ & 1.03 & {$[1.02 ; 1.05]$} & $<0.001$ \\
\hline & & $34.3 \pm 8.9$ & $36.5 \pm 9.6$ & & & & & & \\
\hline Gender & 789 & & & & & & & & \\
\hline Male & & $358(63.6)$ & $161(71.2)$ & 1.32 & {$[0.99 ; 1.76]$} & 0.061 & & & \\
\hline Female & & $205(36.4)$ & $65(28.8)$ & Ref & & & & & \\
\hline Diabetes & 710 & $10(2.0)$ & $7(3.3)$ & 1.98 & {$[0.93 ; 4.22]$} & 0.076 & & & \\
\hline Obesity/Overweight & 686 & $138(28.2)$ & $57(29.1)$ & 1.04 & {$[0.76 ; 1.41]$} & 0.826 & & & \\
\hline Arterial hypertension & 710 & $39(7.8)$ & $18(8.6)$ & 1.03 & {$[0.63 ; 1.66]$} & 0.919 & & & \\
\hline Alcohol intake & 615 & & & 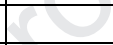 & & 0.014 & & & \\
\hline Never & & $251(58.8)$ & $91(48.4)$ & Ref & & & & & \\
\hline Past & & $38(8.9)$ & $32(17.0)$ & 1.81 & {$[1.21 ; 2.71]$} & 0.004 & & & \\
\hline Ongoing & & $138(32.3)$ & $65(34.6)$ & 1.22 & {$[0.89 ; 1.68]$} & 0.218 & & & \\
\hline Tobacco intake & 571 & & 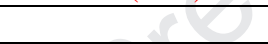 & & & 0.134 & & & \\
\hline Never & & $265(66.4)$ & $94(54.6)$ & Ref & & & & & \\
\hline Past & & $31(7.8)$ & $23(13.4)$ & 1.22 & {$[0.77 ; 1.94]$} & 0.405 & & & \\
\hline Ongoing & & $103(25.8)$ & $55(32.0)$ & 1.40 & {$[1.00 ; 1.95]$} & 0.048 & & & \\
\hline IV drug use & 571 & $67(17.5)$ & $51(27.3)$ & 1.34 & {$[0.97 ; 1.85]$} & 0.075 & & & \\
\hline Route of transmission & 748 & & 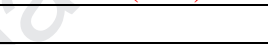 & & & & & & \\
\hline Birth in endemic country & & $428(80.2)$ & $138(64.5)$ & Ref & & & & & \\
\hline Other & & $106(19.8)$ & $76(35.5)$ & 1.46 & {$[1.10 ; 1.93]$} & 0.009 & & & \\
\hline Place of birth & 771 & +2 & & & & $<0.001$ & & & 0.008 \\
\hline France & & $50(9.1)$ & $44(19.7)$ & Ref & & & Ref & & \\
\hline Europe (except France) & & $86(15.7)$ & $34(15.3)$ & 0.93 & {$[0.59 ; 1.46]$} & 0.753 & 0.83 & {$[0.52 ; 1.31]$} & 0.426 \\
\hline Northern Africa/Middle East & & $16(2.9)$ & $22(9.9)$ & 1.76 & {$[1.05 ; 2.96]$} & 0.032 & 2.00 & {$[1.19 ; 3.38]$} & 0.009 \\
\hline Subsaharan Africa & & $356(65.0)$ & $107(48.0)$ & 0.64 & {$[0.45 ; 0.91]$} & 0.013 & 0.83 & {$[0.57 ; 1.19]$} & 0.312 \\
\hline Asia & & $40(7.3)$ & $15(6.7)$ & 1.10 & {$[0.61 ; 1.99]$} & 0.750 & 1.10 & {$[0.60 ; 1.99]$} & 0.760 \\
\hline Anti-HCV antibodies & 672 & & & & & & & & \\
\hline Negative & & $381(81.9)$ & $145(70.1)$ & Ref & & & & & \\
\hline Positive & & $84(18.1)$ & $62(29.9)$ & 1.44 & {$[1.06 ; 1.93]$} & 0.018 & & & \\
\hline Anti-HIV antibodies & 652 & & & & & & & & \\
\hline Negative & & $370(81.7)$ & $152(76.4)$ & Ref & & & & & \\
\hline Positive & & $83(18.3)$ & $47(23.6)$ & 1.06 & {$[0.77 ; 1.48]$} & 0.717 & & & \\
\hline HBV viral load (baseline) & 648 & & & & & & & & \\
\hline Negative & & $230(48.4)$ & $85(49.1)$ & Ref & & & & & \\
\hline Positive & & $245(51.6)$ & $88(50.9)$ & 1.17 & {$[0.87 ; 1.58]$} & 0.296 & & & \\
\hline HDV viral load (baseline) & 550 & & & & & & & & \\
\hline Negative & & $62(15.5)$ & $12(8.1)$ & Ref & & & & & \\
\hline Positive & & $339(84.5)$ & $137(91.9)$ & 1.49 & {$[0.83 ; 2.69]$} & 0.184 & & & \\
\hline HDV viral load (before endpoint) & 748 & & & & & & & & \\
\hline Negative & & $221(41.6)$ & $21(9.7)$ & Ref & & & Ref & & \\
\hline Positive & & $310(58.4)$ & $196(90.3)$ & 5.75 & {$[3.67 ; 9.03]$} & $<0.001$ & 6.11 & {$[3.84 ; 9.77]$} & $<0.001$ \\
\hline
\end{tabular}




\begin{tabular}{|c|c|c|c|c|c|c|c|c|c|}
\hline & & & & \multicolumn{3}{|c|}{ Univariate analysis } & \multicolumn{3}{|c|}{ Multivariate analysis } \\
\hline Features & $\begin{array}{c}\text { Number } \\
\text { of } \\
\text { patients }\end{array}$ & $\begin{array}{c}\text { No cirrhosis } \\
n=563\end{array}$ & $\begin{array}{c}\text { Cirrhosis } \\
\mathrm{n}=226\end{array}$ & HR & 95\% HR CI & P-value & HR & 95\% HR CI & P-value \\
\hline HDV Genotype & 610 & & & & & 0.003 & & & \\
\hline 1 Non Afr & & $146(34.6)$ & $97(51.6)$ & Ref & & & & & \\
\hline $1 \mathrm{Afr}$ & & $158(37.4)$ & $44(23.4)$ & 0.52 & {$[0.36 ; 0.74]$} & $<0.001$ & & & \\
\hline 5 & & $80(19.0)$ & $35(18.6)$ & 0.78 & {$[0.53 ; 1.14]$} & 0.198 & & & \\
\hline Other & & $38(9.0)$ & $12(6.4)$ & 0.58 & {$[0.32 ; 1.06]$} & 0.076 & & & \\
\hline
\end{tabular}


Table 4: Factors associated with the incidence of liver decompensation: univariate and multivariate analysis (Cox proportional hazards regression method)

\begin{tabular}{|c|c|c|c|c|c|c|c|c|c|}
\hline \multirow[b]{2}{*}{ Features } & \multirow[b]{2}{*}{$\begin{array}{c}\text { Number } \\
\text { of } \\
\text { patients }\end{array}$} & \multirow[b]{2}{*}{$\begin{array}{l}\text { No decompensation } \\
\qquad \mathbf{n}=\mathbf{2 7 0}\end{array}$} & \multirow[b]{2}{*}{$\begin{array}{c}\text { Decompensation } \\
n=105\end{array}$} & \multicolumn{3}{|c|}{ Univariate analysis } & \multicolumn{3}{|c|}{ Multivariate analysis } \\
\hline & & & & HR & $95 \%$ HR CI & P-value & HR & 95\% HR CI & P-value \\
\hline Cirrhosis at referral & 375 & $102(37.6)$ & $46(44.2)$ & 1.79 & {$[1.21 ; 2.65]$} & 0.004 & & & \\
\hline Age at patient care (years) & 375 & $37.6[30.7-44.8]$ & $39.3[33.0-45.6]$ & 1.03 & {$[1.01 ; 1.05]$} & 0.008 & 1.04 & {$[1.01 ; 1.06]$} & 0.003 \\
\hline & & $38.0 \pm 10.3$ & $39.0 \pm 10.1$ & & & & & & \\
\hline Gender & 375 & & & & & & & & \\
\hline Male & & $202(74.8)$ & $79(75.2)$ & 0.85 & {$[0.55 ; 1.33]$} & 0.480 & & & \\
\hline Female & & $68(25.2)$ & $26(24.8)$ & Ref & & & & & \\
\hline Diabetes & 350 & $8(3.2)$ & $4(4.1)$ & 1.77 & {$[0.65 ; 4.85]$} & 0.266 & & & \\
\hline Obesity/Overweight & 323 & $60(26.2)$ & $35(37.2)$ & 1.66 & {$[1.08 ; 2.53]$} & 0.020 & 1.88 & {$[1.14 ; 3.09]$} & 0.014 \\
\hline Arterial hypertension & 350 & $24(9.5)$ & $10(10.3)$ & 1.30 & {$[0.67 ; 2.51]$} & 0.437 & & & \\
\hline Alcohol intake & 304 & & 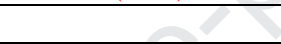 & & & 0.414 & & & \\
\hline Never & & $111(51.9)$ & $38(42.2)$ & Ref & & & & & \\
\hline Past & & $36(16.8)$ & $23(25.6)$ & 1.40 & {$[0.82 ; 2.36]$} & 0.214 & & & \\
\hline Ongoing & & $67(31.3)$ & $29(32.2)$ & 1.26 & {$[0.77 ; 2.04]$} & 0.356 & & & \\
\hline Tobacco intake & 285 & & +2 & & & 0.073 & & & \\
\hline Never & & $115(58.4)$ & $38(43.2)$ & Ref & & & & & \\
\hline Past & & $22(11.2)$ & $22(25.0)$ & 1.85 & {$[1.09 ; 3.16]$} & 0.023 & & & \\
\hline Ongoing & & $60(30.4)$ & $28(31.8)$ & 1.16 & {$[0.71 ; 1.90]$} & 0.542 & & & \\
\hline IV drug use & 287 & $45(22.7)$ & $28(31.5)$ & 1.04 & {$[0.66 ; 1.65]$} & 0.858 & & & \\
\hline Route of transmission & 351 & 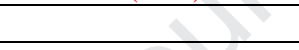 & & & & & & & \\
\hline Birth in endemic country & & $174(69.6)$ & $66(65.4)$ & Ref & & & & & \\
\hline Other & & $76(30.4)$ & $35(34.6)$ & 0.73 & {$[0.47 ; 1.11]$} & 0.138 & & & \\
\hline Place of birth & 372 & 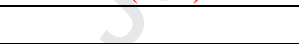 & & & & 0.002 & & & \\
\hline France & & $48(17.9)$ & $21(20.2)$ & Ref & & & & & \\
\hline Europe (except France) & & $50(18.7)$ & $26(25.0)$ & 3.39 & {$[1.83 ; 6.31]$} & $<0.001$ & & & \\
\hline Northern Africa + Middle East & & $23(8.6)$ & $11(10.6)$ & 1.52 & {$[0.70 ; 3.28]$} & 0.287 & & & \\
\hline Subsaharan Africa & & $129(48.1)$ & $41(39.4)$ & 1.32 & {$[0.76 ; 2.27]$} & 0.322 & & & \\
\hline Asia & & $16(6.0)$ & $4(3.8)$ & 1.16 & {$[0.40 ; 3.41]$} & 0.782 & & & \\
\hline Anti-HCV antibodies & 335 & & & & & & & & \\
\hline Negative & & $177(74.4)$ & $64(66.0)$ & Ref & & & & & \\
\hline Positive & & $61(25.6)$ & $33(34.0)$ & 1.01 & {$[0.66 ; 1.55]$} & 0.964 & & & \\
\hline Anti-HIV antibodies & 325 & & & & & & & & \\
\hline Negative & & $179(77.8)$ & $68(71.6)$ & Ref & & & & & \\
\hline Positive & & $51(22.2)$ & $27(28.4)$ & 1.11 & {$[0.71 ; 1.74]$} & 0.653 & & & \\
\hline HBV viral load (baseline) & 290 & & & & & & & & \\
\hline Negative & & $121(55.8)$ & $31(42.5)$ & Ref & & & & & \\
\hline Positive & & $96(44.2)$ & $42(57.5)$ & 1.75 & {$[1.09 ; 2.81]$} & 0.020 & & & \\
\hline HDV viral load (baseline) & 252 & & & & & & & & \\
\hline Negative & & $14(7.4)$ & $7(11.1)$ & Ref & & & & & \\
\hline Positive & & $175(92.6)$ & $56(88.9)$ & 0.70 & {$[0.32 ; 1.55]$} & 0.381 & & & \\
\hline HDV viral load (before endpoint) & 352 & & & & & & & & \\
\hline
\end{tabular}




\begin{tabular}{|c|c|c|c|c|c|c|c|c|c|}
\hline \multirow[b]{2}{*}{ Features } & \multirow[b]{2}{*}{$\begin{array}{c}\text { Number } \\
\text { of } \\
\text { patients }\end{array}$} & \multirow[b]{2}{*}{$\begin{array}{c}\text { No decompensation } \\
\qquad=\mathbf{n} 70\end{array}$} & \multirow[b]{2}{*}{$\begin{array}{c}\text { Decompensation } \\
n=105\end{array}$} & \multicolumn{3}{|c|}{ Univariate analysis } & \multicolumn{3}{|c|}{ Multivariate analysis } \\
\hline & & & & HR & 95\% HR CI & P-value & HR & $95 \%$ HR CI & P-value \\
\hline Negative & & $103(39.9)$ & $24(25.5)$ & Ref & & & & & \\
\hline Positive & & $155(60.1)$ & $70(74.5)$ & 2.78 & {$[1.61 ; 4.82]$} & $<0.001$ & 2.57 & {$[1.42 ; 4.63]$} & 0.002 \\
\hline HDV Genotype & 309 & & & & & 0.921 & & & \\
\hline 1 Non Afr & & $121(52.4)$ & $47(60.3)$ & Ref & & & & & \\
\hline $1 \mathrm{Afr}$ & & $56(24.2)$ & $16(20.5)$ & 0.98 & {$[0.55 ; 1.74]$} & 0.941 & & & \\
\hline 5 & & $42(18.2)$ & $10(12.8)$ & 0.78 & {$[0.39 ; 1.56]$} & 0.487 & & & \\
\hline Others & & $12(5.2)$ & $5(6.4)$ & 0.98 & {$[0.39 ; 2.47]$} & 0.961 & & & \\
\hline AST/SGOT (IU/L) & 358 & & & & & 0.004 & & & \\
\hline$\leq \mathrm{ULN}$ & & $44(17.1)$ & $8(8.0)$ & Ref & & & & & \\
\hline ]ULN ; 2ULN] & & $102(39.5)$ & $33(33.0)$ & 1.72 & {$[0.79 ; 3.74]$} & 0.171 & & & \\
\hline$>2$ ULN & & $112(43.4)$ & $59(59.0)$ & 2.90 & {$[1.38 ; 6.07]$} & 0.005 & & & \\
\hline ALT/SGPT (IU/L) & 358 & & 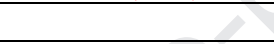 & & & 0.045 & & & \\
\hline$\leq \mathrm{ULN}$ & & $40(15.5)$ & $11(11.0)$ & Ref & & & & & \\
\hline ]ULN ; 2ULN] & & $93(36.1)$ & $46(46.0)$ & 1.72 & {$[0.89 ; 3.32]$} & 0.108 & & & \\
\hline$>2$ ULN & & $125(48.4)$ & $43(43.0)$ & 1.04 & {$[0.54 ; 2.03]$} & 0.898 & & & \\
\hline GGT (IU/L) & 343 & & +2 & & & 0.028 & & & \\
\hline$\leq \mathrm{ULN}$ & & $68(27.3)$ & $18(19.2)$ & Ref & & & & & \\
\hline ]ULN ; 2ULN] & & $79(31.7)$ & $29(30.9)$ & 1.42 & {$[0.77 ; 2.61]$} & 0.262 & & & \\
\hline$>2$ ULN & & $102(41.0)$ & $47(50.0)$ & 2.08 & {$[1.18 ; 3.68]$} & 0.011 & & & \\
\hline Platelet count $\left(10^{3} / \mathrm{mm}^{3}\right)$ & 353 & 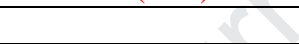 & & & & $<0.001$ & & & $<0.001$ \\
\hline$<100$ & & $66(6.0)$ & $52(52.5)$ & 4.75 & {$[2.82 ; 7.98]$} & $<0.001$ & 4.27 & {$[2.14 ; 8.55]$} & $<0.001$ \\
\hline$[100 ; 150]$ & & $85(33.5)$ & $26(26.3)$ & 1.82 & {$[1.01 ; 3.27]$} & 0.047 & 2.16 & {$[1.04 ; 4.49]$} & 0.040 \\
\hline$>150$ & & $103(40.5)$ & $21(21.2)$ & Ref & & & Ref & & \\
\hline $\operatorname{AFP}(\mathrm{ng} / \mathrm{mL})$ & 241 & 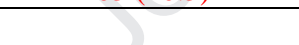 & & & & & & & \\
\hline$\leq$ ULN & & $142(77.6)$ & $40(69.0)$ & Ref & & & & & \\
\hline$>$ ULN & & $41(22.4)$ & $18(31.0)$ & 2.51 & {$[1.43 ; 4.44]$} & 0.001 & & & \\
\hline Albumin $(\mathrm{g} / \mathrm{L})$ & 274 & & & & & & & & \\
\hline$\leq 35$ & & $28(14.4)$ & $37(46.8)$ & 4.48 & {$[2.86 ; 7.02]$} & $<0.001$ & & & \\
\hline$>35$ & & $167(85.6)$ & $42(53.2)$ & Ref & & & & & \\
\hline Total bilirubin $(\mu \mathrm{mol} / \mathrm{L})$ & 337 & & & & & & & & \\
\hline$\leq 17$ & & $172(72.3)$ & $50(50.5)$ & Ref & & & Ref & & \\
\hline$>17$ & & $66(27.7)$ & $49(49.5)$ & 2.70 & {$[1.81 ; 4.02]$} & $<0.001$ & 2.37 & {$[1.36 ; 4.11]$} & 0.001 \\
\hline Prothrombin time (\%) & 335 & & & & & & & & \\
\hline$\leq 80$ & & $142(59.2)$ & $73(76.8)$ & 2.05 & {$[1.27 ; 3.31]$} & 0.003 & & & \\
\hline$>80$ & & $98(40.8)$ & $22(23.2)$ & Ref & & & & & \\
\hline
\end{tabular}


Table 5: Factors associated with the incidence of HCC: univariate and multivariate analysis (Cox proportional hazards regression method)

\begin{tabular}{|c|c|c|c|c|c|c|c|c|c|}
\hline \multirow{3}{*}{\multicolumn{2}{|c|}{\begin{tabular}{l|c} 
Features & $\begin{array}{c}\text { Number } \\
\text { of } \\
\text { patients }\end{array}$ \\
Cirrhosis at referral & 1074
\end{tabular}}} & \multirow[b]{2}{*}{$\begin{array}{c}\text { No HCC } \\
\text { n=1004 }\end{array}$} & \multirow[b]{2}{*}{$\begin{array}{l}\mathrm{HCC} \\
\mathrm{n}=72\end{array}$} & \multicolumn{3}{|c|}{ Univariate analysis } & \multicolumn{3}{|c|}{ Multivariate analysis } \\
\hline & & & & HR & 95\% HR CI & P-value & HR & $95 \%$ HR CI & P-value \\
\hline & & $248(24.8)$ & $37(51.4)$ & 4.82 & {$[3.00 ; 7.73]$} & $<0.001$ & & & \\
\hline Liver decompensation at referral & 1076 & $130(13.0)$ & $17(23.6)$ & 5.95 & {$[3.34 ; 10.60]$} & $<0.001$ & & & \\
\hline Age at patient care (years) & 1076 & $35.5[29.5-42.3]$ & $41.9[36.2-49.4]$ & 1.09 & {$[1.06 ; 1.11]$} & $<0.001$ & 1.08 & {$[1.05 ; 1.12]$} & $<0.001$ \\
\hline & & $35.9 \pm 9.5$ & $42.8 \pm 9.7$ & +2 & & & & & \\
\hline Gender & 1076 & & & +2 & & & & & \\
\hline Male & & $676(67.3)$ & $58(80.6)$ & 1.76 & {$[0.98 ; 3.16]$} & 0.060 & & & \\
\hline Female & & $328(32.7)$ & $14(19.4)$ & Ref & & & & & \\
\hline Diabetes & 983 & $25(2.7)$ & $6(9.5)$ & 5.38 & {$[2.29 ; 12.61]$} & $<0.001$ & & & \\
\hline Obesity/Overweight & 938 & $253(28.9)$ & $25(39.7)$ & 1.56 & {$[0.92 ; 2.62]$} & 0.096 & & & \\
\hline Arterial hypertension & 986 & $76(8.2)$ & $10(15.6)$ & 1.86 & {$[0.94 ; 3.66]$} & 0.072 & & & \\
\hline Alcohol intake & 842 & & nes & & & $<0.001$ & & & 0.027 \\
\hline Never & & $436(55.8)$ & $23(37.7)$ & Ref & & & Ref & & \\
\hline Past & & $111(14.2)$ & $21(34.4)$ & 3.26 & {$[1.80 ; 5.91]$} & $<0.001$ & 2.39 & {$[1.22 ; 4.64]$} & 0.010 \\
\hline Ongoing & & $234(30.0)$ & $17(27.9)$ & 1.21 & {$[0.63 ; 2.33]$} & 0.558 & 1.11 & {$[0.53 ; 2.30]$} & 0.789 \\
\hline Tobacco intake & 800 & & & & & 0.199 & & & \\
\hline Never & & $431(58.3)$ & $32(52.5)$ & Ref & & & & & \\
\hline Past & & $94(12.7)$ & $6(9.8)$ & 0.73 & {$[0.30 ; 1.76]$} & 0.483 & & & \\
\hline Ongoing & & $214(29.0)$ & $23(37.7)$ & 1.48 & {$[0.86 ; 2.56]$} & 0.157 & & & \\
\hline IV drug use & 765 & $153(21.7)$ & $18(30.0)$ & 1.34 & {$[0.76 ; 2.34]$} & 0.307 & & & \\
\hline Route of transmission & 1015 & & & & & & & & \\
\hline Birth in endemic country & & $711(74.9)$ & $43(65.2)$ & Ref & & & & & \\
\hline Other & & $238(25.1)$ & $23(34.8)$ & 1.15 & {$[0.69 ; 1.93]$} & 0.592 & & & \\
\hline Place of birth & 1054 & & & & & 0.105 & & & \\
\hline France & & $133(13.5)$ & $14(20.0)$ & Ref & & & & & \\
\hline Europe (except France) & & $210(21.3)$ & $13(18.6)$ & 1.65 & {$[0.74 ; 3.66]$} & 0.220 & & & \\
\hline Northern Africa/Middle East & & $55(5.6)$ & $9(12.9)$ & 2.49 & {$[1.05 ; 5.92]$} & 0.038 & & & \\
\hline Subsaharan Africa & & $522(53.1)$ & $32(45.7)$ & 0.92 & {$[0.47 ; 1.78]$} & 0.799 & & & \\
\hline Asia & & $62(6.3)$ & $2(2.9)$ & 0.73 & {$[0.16 ; 3.27]$} & 0.682 & & & \\
\hline Anti-HCV antibodies & 924 & & & & & & & & \\
\hline Negative & & $658(76.4)$ & $44(69.8)$ & Ref & & & & & \\
\hline Positive & & $203(23.6)$ & $19(30.2)$ & 1.17 & {$[0.68 ; 2.01]$} & 0.563 & & & \\
\hline Anti-HIV antibodies & 903 & & & & & & & & \\
\hline Negative & & $675(80.5)$ & $51(79.7)$ & Ref & & & & & \\
\hline Positive & & $164(19.5)$ & $13(20.3)$ & 0.79 & {$[0.43 ; 1.46]$} & 0.461 & & & \\
\hline HBV viral load (baseline) & 855 & & & & & & & & \\
\hline Negative & & $413(51.3)$ & $30(60.0)$ & Ref & & & & & \\
\hline
\end{tabular}


Univariate analysis

Multivariate analysis

\begin{tabular}{|c|c|c|c|c|c|c|c|c|c|}
\hline \multirow{2}{*}{\begin{tabular}{|l} 
\\
Features
\end{tabular}} & \multirow{2}{*}{$\begin{array}{c}\text { Number } \\
\text { of } \\
\text { patients }\end{array}$} & & & \multicolumn{3}{|c|}{ Univariate analysis } & \multicolumn{3}{|c|}{ Multivariate analysis } \\
\hline & & $\begin{array}{c}\text { No HCC } \\
n=1004\end{array}$ & $\begin{array}{l}\text { HCC } \\
n=72\end{array}$ & HR & 95\% HR CI & P-value & HR & $95 \%$ HR CI & P-value \\
\hline Positive & & $392(48.7)$ & $20(40.0)$ & 0.76 & {$[0.42 ; 1.37]$} & 0.365 & & & \\
\hline HDV viral load (baseline) & 727 & & & & & & & & \\
\hline Negative & & $79(11.7)$ & $8(16.3)$ & Ref & & & & & \\
\hline Positive & & $599(88.3)$ & $41(83.7)$ & 0.62 & {$[0.28 ; 1.39]$} & 0.248 & & & \\
\hline HDV viral load (before endpoint) & 954 & & & & & & & & \\
\hline Negative & & $342(38.3)$ & $15(25.0)$ & Ref & (2) & & & & \\
\hline Positive & & $552(61.7)$ & $45(75.0)$ & 2.46 & {$[1.35 ; 4.48]$} & 0.003 & & & \\
\hline HDV Genotype & 812 & & & & 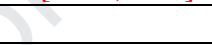 & 0.643 & & & \\
\hline 1 Non Afr & & $340(44.9)$ & $28(50.9)$ & Ref & 20 & & & & \\
\hline $1 \mathrm{Afr}$ & & $227(30.0)$ & $12(21.8)$ & 0.67 & {$[0.34 ; 1.31]$} & 0.241 & & & \\
\hline 5 & & $133(17.6)$ & $11(20.0)$ & 1.06 & {$[0.53 ; 2.14]$} & 0.866 & & & \\
\hline Other & & $57(7.5)$ & $4(7.3)$ & 0.87 & {$[0.30 ; 2.48]$} & 0.794 & & & \\
\hline AST/SGOT (IU/L) & 1019 & & 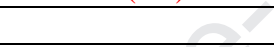 & 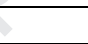 & & 0.028 & & & \\
\hline$\leq \mathrm{ULN}$ & & $230(24.2)$ & $7(10.4)$ & Ref & & & & & \\
\hline ]ULN ; 2ULN] & & $360(37.8)$ & $28(41.8)$ & 2.27 & {$[0.98 ; 5.23]$} & 0.054 & & & \\
\hline >2ULN & & $362(38.0)$ & $32(47.8)$ & 3.02 & {$[1.33 ; 6.85]$} & 0.008 & & & \\
\hline ALT/SGPT (IU/L) & 1023 & & +2 & & & 0.043 & & & \\
\hline$\leq$ ULN & & $255(26.7)$ & $13(19.4)$ & Ref & & & & & \\
\hline ]ULN ; 2ULN] & & $318(33.3)$ & $31(46.3)$ & 1.77 & {$[0.90 ; 3.46]$} & 0.096 & & & \\
\hline$>2$ ULN & & $383(40.0)$ & $23(34.3)$ & 0.92 & {$[0.46 ; 1.85]$} & 0.810 & & & \\
\hline GGT (IU/L) & 974 & & & & & $<0.001$ & & & 0.002 \\
\hline$\leq \mathrm{ULN}$ & & $399(43.8)$ & $12(19.4)$ & Ref & & & Ref & & \\
\hline ]ULN ; 2ULN] & & $272(29.8)$ & $18(29.0)$ & 2.01 & {$[0.94 ; 4.28]$} & 0.072 & 1.52 & {$[0.62 ; 3.76]$} & 0.361 \\
\hline$>2$ ULN & & $241(16.4)$ & $32(51.6)$ & 4.33 & {$[2.18 ; 8.58]$} & $<0.001$ & 3.70 & {$[1.63 ; 8.43]$} & 0.002 \\
\hline Platelet count $\left(10^{3} / \mathrm{mm}^{3}\right)$ & 1007 & +2 & & & & $<0.001$ & & & 0.040 \\
\hline$<100$ & & $216(23.0)$ & $32(47.1)$ & 6.96 & {$[3.78 ; 12.80]$} & $<0.001$ & 2.56 & {$[1.19 ; 5.49]$} & 0.016 \\
\hline$[100 ; 150]$ & & $210(22.4)$ & $19(27.9)$ & 2.84 & {$[1.46 ; 5.54]$} & 0.002 & 1.41 & {$[0.63 ; 3.14]$} & 0.407 \\
\hline$>150$ & & $513(54.6)$ & $17(25.0)$ & Ref & & & Ref & & \\
\hline AFP (ng/mL) & 590 & & & & & $<0.001$ & & & \\
\hline$\leq \mathrm{ULN}$ & & $458(84.4)$ & $30(63.8)$ & Ref & & & & & \\
\hline >ULN & & $85(15.6)$ & $17(36.2)$ & 4.33 & {$[2.38 ; 7.91]$} & $<0.001$ & & & \\
\hline Albumin $(\mathrm{g} / \mathrm{L})$ & 750 & & & & & & & & \\
\hline$\leq 35$ & & $167(24.0)$ & $20(37.0)$ & 3.08 & {$[1.75 ; 5.43]$} & $<0.001$ & & & \\
\hline$>35$ & & $529(76.0)$ & $34(63.0)$ & Ref & & & & & \\
\hline Total bilirubin $(\mu \mathrm{mol} / \mathrm{L})$ & 942 & & & & & & & & \\
\hline$\leq 17$ & & $591(67.2)$ & $32(50.8)$ & Ref & & & & & \\
\hline$>17$ & & $288(32.8)$ & $31(49.2)$ & 2.95 & {$[1.78 ; 4.89]$} & $<0.001$ & & & \\
\hline Prothrombin time (\%) & 927 & & & & & & & & \\
\hline$\leq 80$ & & $441(51.1)$ & $52(81.3)$ & 4.62 & {$[2.41 ; 8.87]$} & $<0.001$ & 4.15 & {$[1.88 ; 9.18]$} & $<0.001$ \\
\hline$>80$ & & $422(48.9)$ & $12(18.8)$ & Ref & & & Ref & & \\
\hline
\end{tabular}


Table 6 : Factors associated with survival without transplantation: univariate and multivariate analysis (Cox proportional hazards regression method)

\begin{tabular}{|c|c|c|c|c|c|c|c|c|}
\hline \multirow[b]{2}{*}{ Features } & \multicolumn{5}{|l|}{ Univariate analysis } & \multicolumn{3}{|c|}{ Multivariate analysis } \\
\hline & $\begin{array}{c}\text { Absence of death and } \\
\text { liver transplantation } \\
\mathbf{n}=\mathbf{8 8 7}\end{array}$ & $\begin{array}{c}\text { Presence of death or liver } \\
\text { transplantation } \\
n=188\end{array}$ & HR & 95\% HR CI & $P$ value & aHR & $95 \%$ aHR CI & $P$ value \\
\hline Age at care (years) & $35.2[29.2-42.4]$ & $39.0[33.6-44.7]$ & 1.04 & {$[1.02-1.05]$} & $<0.001$ & & & \\
\hline Cirrhosis & $35.1 \%$ & $95.6 \%$ & 53.53 & {$[23.71-120.87]$} & $<0.001$ & 17.05 & [6.09-47.77] & $<0.001$ \\
\hline Diabetes & $2.6 \%$ & $5.6 \%$ & 2.37 & {$[1.21-4.64]$} & 0.012 & & & \\
\hline Alcohol intake & & & $\sqrt{3}$ & & 0.034 & 2.71 & {$[1.75-4.21]$} & $<0.001$ \\
\hline Never & $57.4 \%$ & $42.2 \%$ & Ref & & & & & \\
\hline Past & $11.2 \%$ & 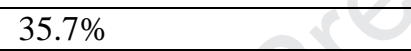 & 3.01 & {$[2.08-4.35]$} & $<0.001$ & & & \\
\hline Ongoing & $31.4 \%$ & 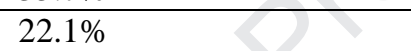 & 0.99 & {$[0.65-1.50]$} & 0.96 & & & \\
\hline Place of birth & & +2 & & & $<0.001$ & & & \\
\hline France & $12.5 \%$ & $20.9 \%$ & Ref & & & & & \\
\hline Europe (except France) & $16.6 \%$ & $42.2 \%$ & 2.81 & {$[1.85-4.25]$} & $<0.001$ & & & \\
\hline Northern Africa + Middle East & $5.0 \%$ & $11.2 \%$ & 1.74 & [0.99-3.03] & 0.051 & & & \\
\hline Subsaharan Africa & $58.7 \%$ & $24.6 \%$ & 0.41 & {$[0.26-0.65]$} & $<0.001$ & & & \\
\hline Asia & $7.2 \%$ & $1.1 \%$ & 0.21 & {$[0.05-0.89]$} & 0.034 & & & \\
\hline HDV viral load before endpoint* & & +3 & & & & & & \\
\hline Negative & $40.6 \%$ & $16.7 \%$ & Ref & & & Ref & & \\
\hline Positive & $59.4 \%$ & $83.3 \%$ & 3.92 & {$[2.40-6.42]$} & $<0.001$ & 3.30 & {$[1.93-5.66]$} & $<0.001$ \\
\hline HDV genotype & & & & & $<0.001$ & & & \\
\hline $1 \&$ no Subsaharan Africa & $42.0 \%$ & $66.4 \%$ & Ref & & & & & \\
\hline $1 \&$ Subsaharan Africa & $31.3 \%$ & $17.3 \%$ & 0.37 & {$[0.22-0.63]$} & $<0.001$ & & & \\
\hline 5 & $18.2 \%$ & $14.5 \%$ & 0.56 & {$[0.32-0.98]$} & 0.044 & & & \\
\hline Others & $8.4 \%$ & $1.8 \%$ & 0.16 & {$[0.04-0.66]$} & 0.011 & & & \\
\hline GGT (IU/L) & & & & & $<0.001$ & & & \\
\hline$\leq \mathrm{N}$ & $45.7 \%$ & $25.2 \%$ & Ref & & & & & \\
\hline$] \mathrm{N} ; 2 \mathrm{~N}]$ & $28.5 \%$ & $35.9 \%$ & 1.84 & {$[1.24-2.73]$} & 0.003 & & & \\
\hline$>2 \mathrm{~N}$ & $25.8 \%$ & $38.9 \%$ & 2.08 & [1.40-3.09] & $<0.001$ & & & \\
\hline Platelet count $\left(10^{3} / \mathrm{mm}^{3}\right)$ & & & & & $<0.001$ & & & 0.003 \\
\hline$<100$ & $15.1 \%$ & $68.7 \%$ & 21.32 & {$[12.95-35.12]$} & $<0.001$ & 3.08 & {$[1.60-5.92]$} & 0.001 \\
\hline$] 100 ; 150]$ & $23.3 \%$ & $20.1 \%$ & 4.68 & {$[2.65-8.26]$} & $<0.001$ & 1.91 & {$[0.96-3.80]$} & 0.63 \\
\hline$>150$ & $61.6 \%$ & $11.2 \%$ & Ref & & & Ref & & \\
\hline $\operatorname{Albumin}(\mathrm{g} / \mathrm{L})$ & & & & & & & & \\
\hline
\end{tabular}




\begin{tabular}{|c|c|c|c|c|c|c|c|c|}
\hline$\leq 35$ & $15.3 \%$ & $65.1 \%$ & 9.20 & [6.48-13.06] & $<0.001$ & & & \\
\hline$>35$ & $84.7 \%$ & $34.9 \%$ & Ref & & & & & \\
\hline \multicolumn{9}{|c|}{ Total bilirubin $(\mu \mathrm{mol} / \mathrm{L})$} \\
\hline$\leq 17$ & $75.5 \%$ & $26.3 \%$ & Ref & & & Ref & & \\
\hline$>17$ & $32.8 \%$ & $73.7 \%$ & 8.10 & [5.73-11.46] & $<0.001$ & 2.97 & [1.80-4.92] & $<0.001$ \\
\hline \multicolumn{9}{|c|}{ Prothrombin time (\%) } \\
\hline$\leq 80$ & $44.8 \%$ & $88.8 \%$ & 8.18 & [5.02-13.33] & $<0.001$ & & & \\
\hline$>80$ & $55.2 \%$ & $11.2 \%$ & Ref & & & & & \\
\hline
\end{tabular}

*Negative if negative before endpoint and maintained until end of follow-up; positive if positive or negative before endpoint and positive after endpoint 


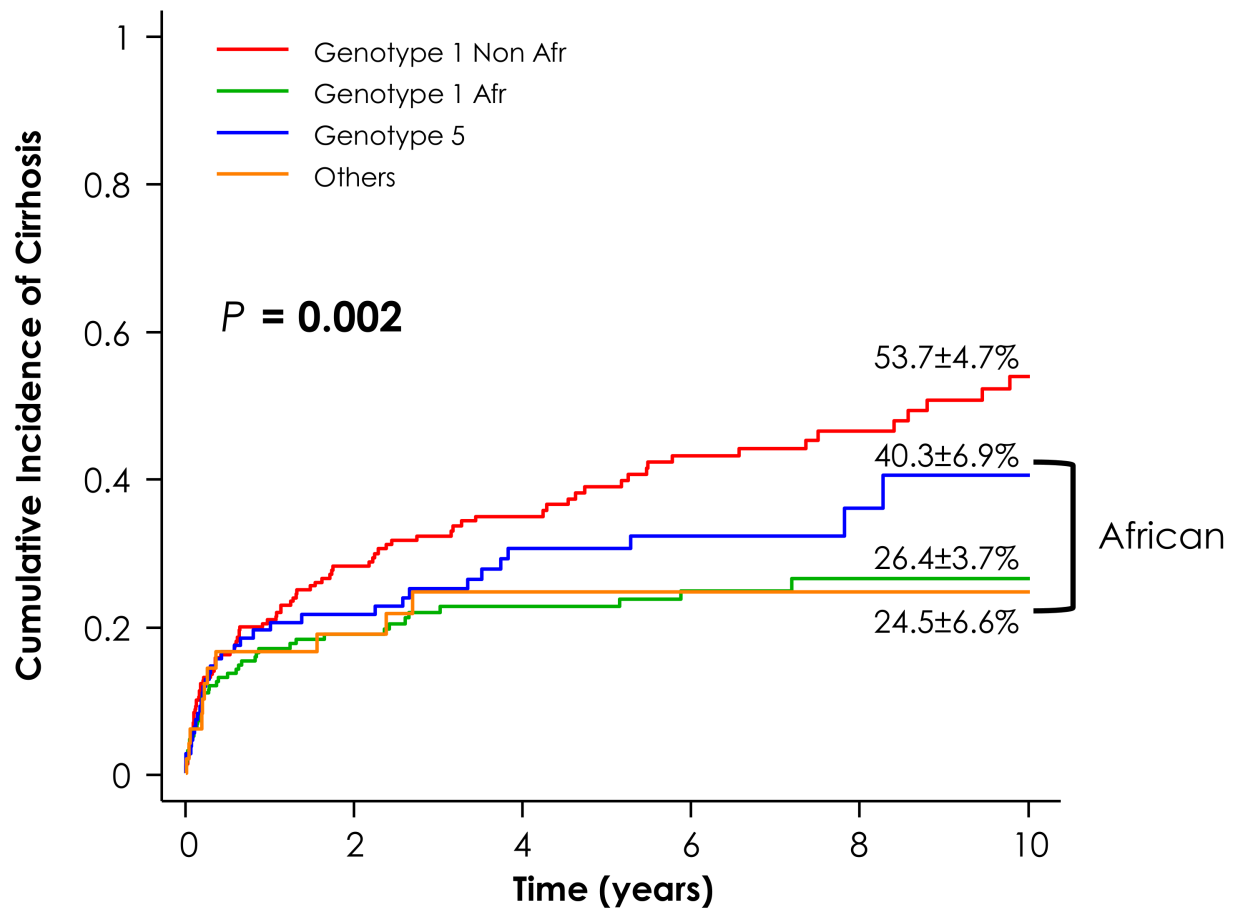

\begin{tabular}{|l|ccccccccccc|}
\hline Genotype & \multicolumn{10}{|l|}{ Number at risk (events) } \\
\hline $\mathbf{1}$ Non Afr & 243 & $(61)$ & 127 & $(11)$ & 88 & $(10)$ & 62 & $(3)$ & 43 & $(5)$ & 25 \\
$\mathbf{1}$ Afr & 202 & $(35)$ & 120 & $(5)$ & 83 & $(2)$ & 65 & $(1)$ & 38 & $(0)$ & 19 \\
5 & 115 & $(23)$ & 69 & $(7)$ & 46 & $(1)$ & 28 & $(1)$ & 14 & $(1)$ & 9 \\
Others & 50 & $(9)$ & 31 & $(2)$ & 20 & $(0)$ & 11 & $(0)$ & 6 & $(0)$ & 4 \\
\hline
\end{tabular}



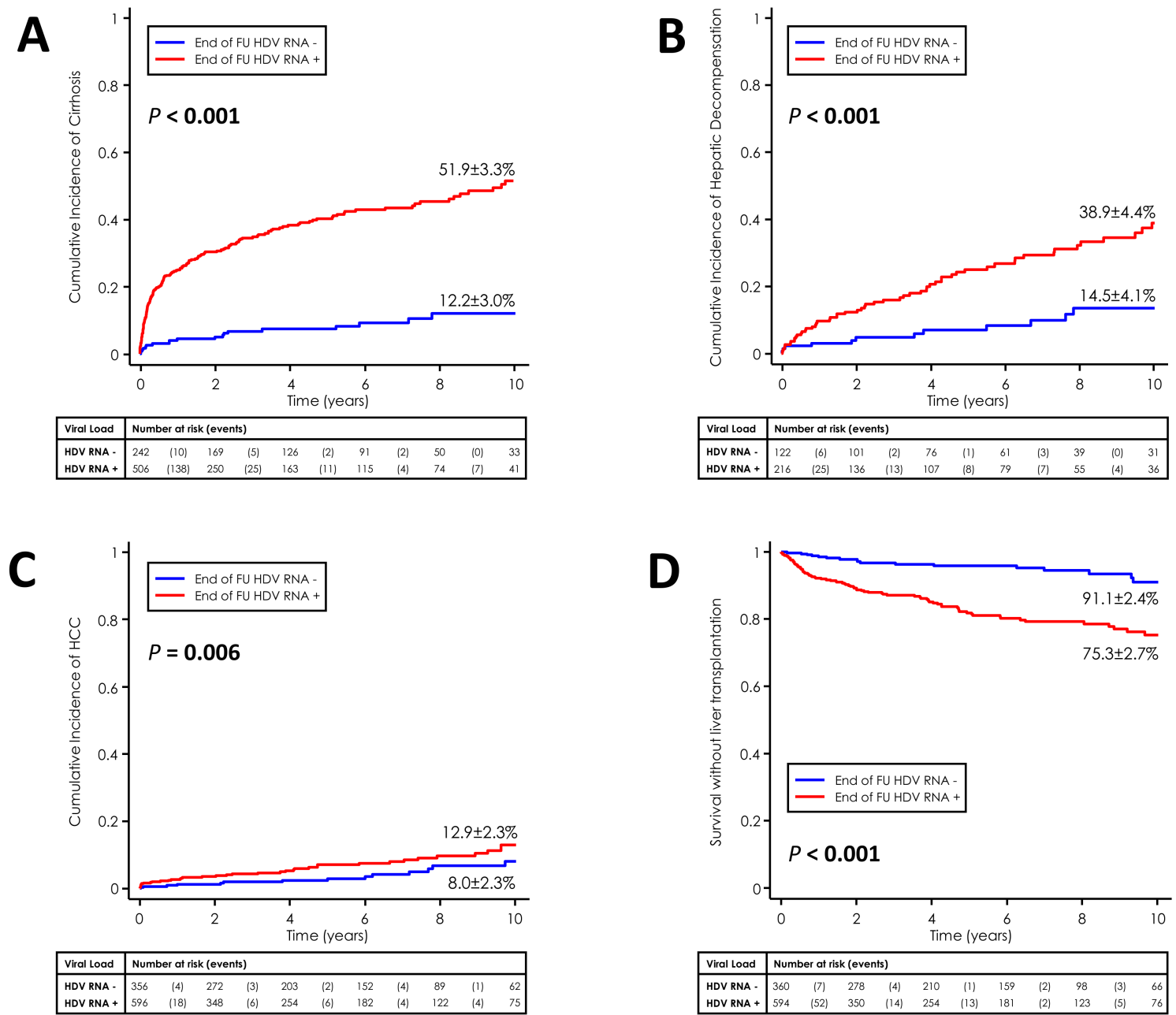

\begin{tabular}{|l|lllllllllll|}
\hline Viral Load & \multicolumn{10}{|l|}{ Number at risk (events) } \\
\hline HDV RNA - & 356 & $(4)$ & 272 & $(3)$ & 203 & $(2)$ & 152 & $(4)$ & 89 & $(1)$ & 62 \\
HDV RNA + & 596 & $(18)$ & 348 & $(6)$ & 254 & $(6)$ & 182 & $(4)$ & 122 & $(4)$ & 75 \\
\hline
\end{tabular}




\section{Highlights}

- Determinants of hepatitis delta severity were studied in a large French cohort

- Some HDV genotypes were associated with higher risk of developing cirrhosis

- African immigrants displayed better response to treatment than non-African patients

- Persistent replicative HDV infection was associated with poor prognosis 